\title{
Perinatal vs Genetic Programming of Serotonin States Associated with Anxiety
}

\author{
Stefanie C Altieri' ${ }^{1,2}$, Hongyan Yang', Hannah J O’Brien', Hannah M Redwine ${ }^{3}$, Damla Senturk ${ }^{4}$, \\ Julie G Hensler ${ }^{3}$ and Anne M Andrews*, 1,2 \\ 'Semel Institute for Neuroscience and Human Behavior and Hatos Center for Neuropharmacology, David Geffen School of Medicine, and \\ California NanoSystems Institute, University of California, Los Angeles, CA, USA; ${ }^{2}$ Huck Institutes of the Life Sciences, The Pennsylvania State \\ University, University Park, PA, USA; ${ }^{3}$ Department of Pharmacology, University of Texas Health Science Center, San Antonio, TX, USA; \\ ${ }^{4}$ Department of Biostatistics, Fielding School of Public Health, University of California, Los Angeles, CA, USA
}

\begin{abstract}
Large numbers of women undergo antidepressant treatment during pregnancy; however, long-term consequences for their offspring remain largely unknown. Rodents exposed to serotonin transporter (SERT)-inhibiting antidepressants during development show changes in adult emotion-like behavior. These changes have been equated with behavioral alterations arising from genetic reductions in SERT. Both models are highly relevant to humans yet they vary in their time frames of SERT disruption. We find that anxiety-related behavior and, importantly, underlying serotonin neurotransmission diverge between the two models. In mice, constitutive loss of SERT causes life-long increases in anxiety-related behavior and hyperserotonemia. Conversely, early exposure to the antidepressant escitalopram (ESC; Lexapro) results in decreased anxiety-related behavior beginning in adolescence, which is associated with adult serotonin system hypofunction in the ventral hippocampus. Adult behavioral changes resulting from early fluoxetine (Prozac) exposure were different from those of ESC and, although somewhat similar to SERT deficiency, were not associated with changes in hippocampal serotonin transmission in late adulthood. These findings reveal dissimilarities in adult behavior and neurotransmission arising from developmental exposure to different widely prescribed antidepressants that are not recapitulated by genetic SERT insufficiency. Moreover, they support a pivotal role for serotonergic modulation of anxiety-related behavior.

Neuropsychopharmacology (20I5) 40, I456-|470; doi:I 0.I038/npp.20I4.33I; published online 28 January 2015
\end{abstract}

\section{INTRODUCTION}

In the United States, $15 \%$ of pregnant women suffer from anxiety disorders and depression (Cahir et al, 2007; Oberlander et al, 2006), and many are prescribed antidepressants. As a result, $5 \%$ of babies born in the United States (200 000/year) are exposed via maternal transmission to selective-serotonin reuptake inhibitors (SSRIs), the most widely prescribed class of antidepressants. Withdrawal effects (Nordeng et al, 2001) and delayed motor coordination (Casper et al, 2003) have been observed in infants exposed to SSRIs in utero. Internalizing behaviors, ie, isolation, somatic complaints, and anxious/depressed behaviors, may also be more prevalent in these children (Oberlander et al, 2009). However, not all studies report behavioral changes in the offspring of mothers taking SSRIs during pregnancy (Casper et al, 2003; Misri et al, 2006).

*Correspondence: Dr AM Andrews, Semel Institute for Neuroscience and Human Behavior and Hatos Center for Neuropharmacology, David Geffen School of Medicine, and California NanoSystems Institute, University of California, Neuroscience Research Building, 635 Charles E. Young Dr S, Box 957332, Los Angeles, CA 90095-7332, USA, Tel: + | 3107949421 , Fax: + | 310983 1133,

E-mail: aandrews@mednet.ucla.edu

Received 27 August 2014; revised 5 December 2014; accepted 7 December 2014; accepted article preview online 19 December 2014
Furthermore, although the first SSRI to be prescribed in the United States, fluoxetine, has now been available for 25 years (Wenthur et al, 2014), no studies have examined the long-term behavioral consequences for adult offspring of mothers who took this drug during pregnancy.

Although poorly studied in humans, long-term behavioral effects associated with developmental antidepressant exposure in rodents have been widely studied (Oberlander et al, 2009; Vogel et al, 1990). Administration of serotonin transporter (SERT)-inhibiting antidepressants to mice or rats during the first 3 weeks after birth alters a range of adult behaviors, including sexual activity, rapid eye movement sleep, exploratory behavior, behavioral despair, and learning. This critical postnatal period of vulnerability in rodents corresponds to the third trimester of pregnancy through the first year of life in humans in terms of brain development (Clancy et al, 2007; Workman et al, 2013).

In addition to inhibition by antidepressants, SERT function is potentially modified by a number of commonly occurring human SERT gene (SLC6A4) polymorphisms (Murphy et al, 2013; Murphy and Moya, 2011). Reductions in SERT associated with low-expressing SLC6A4 alleles have most often been linked to heightened anxiety-related personality traits (eg, neuroticism), stress-sensitivity, and increased susceptibility to mood disorders (Caspi et al, 2010; Mitchell et al, 2011). Rodents do not natively express 
Sert gene polymorphisms analogous to those in humans. Nevertheless, mice and rats with constitutive differences in SERT expression have been engineered (Bengel et al, 1998; Homberg et al, 2007; Jennings et al, 2006). SERT expression, which is decreased by $>50 \%$ in human lymphoblasts with low-expressing 5-HTTLPR and rs25531 allelic combinations ( $\mathrm{Hu}$ et al, 2006) is modeled here by mice lacking one functional Sert allele (SERT $+/$ - mice). Like humans, the most consistent behavioral phenotype associated with SERT deficiency or overexpression in rodents involves elevated or reduced anxiety-like behavior, respectively (Holmes et al, 2003a; Murphy and Lesch, 2008b; Olivier et al, 2008). SERTdeficient mice also show enhanced stress sensitivity (Li et al, 1999; Tjurmina et al, 2002).

In previous studies, altered locomotor, exploratory, and in some cases, depression-like behaviors in rodents following postnatal SSRI exposure have been equated to the effects of constitutive SERT deficiency (Ansorge et al, 2008; Ansorge et al, 2004; Yu et al, 2014). Interpretations of behavioral similarities led to the idea that the effects of SLC6A4 gene polymorphisms might be limited to sensitive developmental periods (Homberg et al, 2010; Sibille and Lewis, 2006). Although attractive, the notion that brief early-life SERT inhibition recapitulates life-long constitutive SERT deficiency seems unlikely, because it neglects to account for the ongoing effects of genetic reductions in SERT on serotonin neurotransmission (Mathews et al, 2004; Yang et al, 2013). We alternately theorized that these two modes of SERT disruption lead to divergent neurochemical endophenotypes (hyperserotonergic vs hyposerotonergic; Figure 1) that produce opposing changes in anxiety-related behavior. Testing this hypothesis is important for delineating the roles of SERT and serotonin neurotransmission in the development and maintenance of anxiety-related behavioral states and understanding the potential influence of developmental antidepressant exposure on adult behavior and susceptibility to neuropsychiatric disorders.

\section{MATERIALS AND METHODS}

\section{Animals and Treatments}

Mice lacking one functional SERT allele (SERT $+/-$ mice) on a CD-1 $\times 129$ SvEv background were bred to produce SERT $+I+$, SERT $+I-$, and SERT $-I-$ mice. For postnatal antidepressant exposure, SERT $+I+$ mice from this line were bred for one generation to produce wild-type animals on the same genetic background as SERT-deficient mice. SERT-deficient mice on this background have been intercrossed continuously since 1997 to produce a congenic line with robust breeding characteristics and adult anxietylike behavior similar to SERT-deficient mice on a C57BL/6J background (Bengel et al, 1998; Mathews et al, 2004; Perez and Andrews, 2005). All mice were maintained on a 12-h light/dark cycle (lights off at 1500 hours) with ad libitum food and water. Procedures involving animals were approved by local Animal Care and Use Committees and were in accordance with the National Institutes of Health Animal Care and Use Guidelines.

For the periadolescent study, 163 mice in groups of 8-16 mice per sex and drug treatment were studied. A total of 420 mice were studied with respect to the adult time points.
Here, groups contained 13-28 mice per sex, age, and genotype or drug treatment (Supplementary Table S1). Wild-type neonates used for postnatal antidepressant exposure were weighed daily beginning on P5 and ending on P21 to determine dosing solution volumes. This postnatal time frame has been identified as a critical developmental window during which exposure to drugs that inhibit SERT generate lasting changes in emotion-related behavior in rodents (Ansorge et al, 2008; Ansorge et al, 2004; Karpova et al, 2009; Maciag et al, 2006; Mirmiran et al, 1981; Popa et al, 2008; Vogel et al, 1990). Mice were injected subcutaneously (sc) with saline, fluoxetine (FLX; $10 \mathrm{mg} / \mathrm{kg} /$ day) or ESC (10 mg/kg/day). Drug doses were calculated for the free bases. Rationales for these doses and administration time frames were based on previous studies demonstrating the persistent effects of similar dose regimens on physiology and behavior after early postnatal exposure in mice (Ansorge et al, 2008; Popa et al, 2008). For the periadolescent portion of the study, ESC-treated mice were directly compared with saline-injected controls, as well as uninjected, unhandled mice.

Drugs were dissolved in sterile, endotoxin-free saline at $1 \mathrm{mg} / \mathrm{ml}$. Injection volumes were $10 \mathrm{ml} / \mathrm{kg}$. During brief, 5-min periods of maternal separation for injections, nests containing all pups were transferred to containers of warmed, dry rice to maintain pup body temperatures. Following weighing and injections, nests were immediately returned to their mothers in the home cages. Saline, FLX, and ESC treatment were randomized across pups in each litter. Injections started $1 \mathrm{~h}$ before the onset of the dark cycle. Offspring of SERT $+I-$ parents were not handled or injected, because mice deficient in SERT display heightened sensitivity to stressful stimuli, including saline injection (Li et al, 1999; Tjurmina et al, 2002). Moreover, the overwhelming majority of previous studies on emotionrelated behavior in mice with genetically manipulated Sert levels have not involved animals subjected to postnatal injection paradigms.

Postnatal antidepressant-treated and SERT-deficient mice were tested on measures of anxiety-, depression-, and activity-related behavior beginning at 2, 3, or 10 months of age. A single investigator (SCA) carried out all drug treatments, handling, and behavior testing. Behavior testing took place during the dark phase under dim light simulating ethologically relevant conditions where rodents are most active. Behavior tests were conducted 3 days apart in the order listed below such that swim or injection stress did not influence behavior in the elevated plus maze. Behavior variables were scored in either an automated fashion or by trained observers who were blind to group assignment.

\section{Elevated Plus Maze}

The elevated plus maze was used to assess anxiety-related behavior (Walf and Frye, 2007). A single maze was used throughout the study having two opposing open arms $(30 \mathrm{~cm}$ length $\times 5 \mathrm{~cm}$ width) with a $0.5-\mathrm{cm}$ lip around the edges of the open arms to prevent animals from falling (Lapiz-Bluhm et al, 2008). The maze also had two opposing closed arms ( $30 \mathrm{~cm}$ length $\times 5 \mathrm{~cm}$ width $\times 15 \mathrm{~cm}$ height $)$ and a center platform $(5 \mathrm{~cm} \times 5 \mathrm{~cm})$ and was raised $38.5 \mathrm{~cm}$ from the floor. The walls of the closed arms were constructed of 


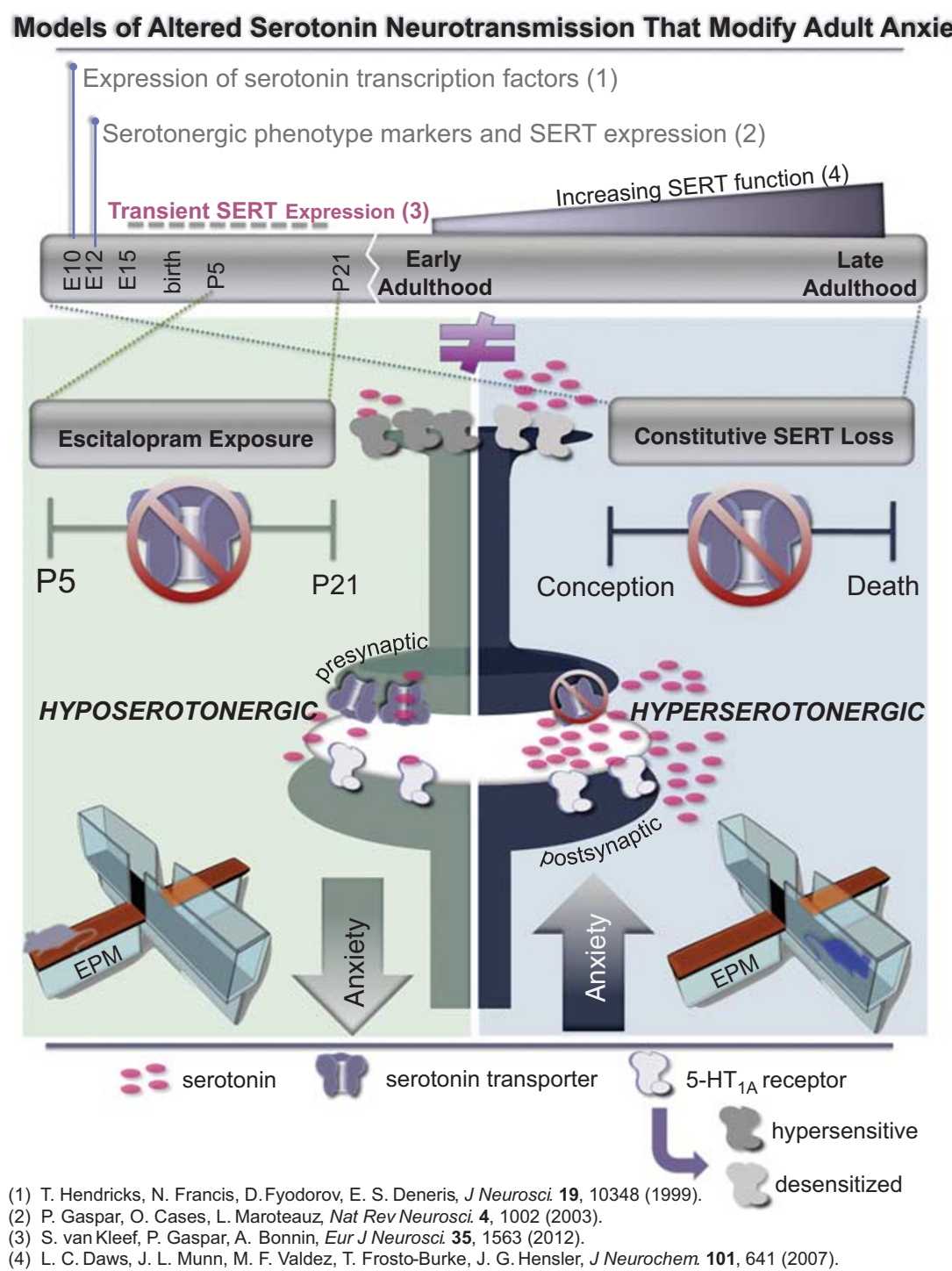

Figure I Different time frames of serotonin transporter (SERT) disruption and effects on serotonin transmission and anxiety-related behavior. Synthesis of brain serotonin begins during early embryonic development in mice (embryonic (E) day 12.5) and is preceded by the expression of transcription factors, ie, Pet-I ETS, LmxIb, and Gata3, necessary for serotonergic phenotype determination ( I and 2). Serotonin transporter expression is observed as early as EI2.5 in brain stem serotonin neurons and also occurs briefly in nonserotonergic neurons ( $\sim$ II through postnatal $(P)$ day $2 \mathrm{I}$ ), predominately in thalamic glutamatergic neurons projecting to cortical sensory processing areas (3). Serotonin transporter expression and function continue to increase throughout adulthood (4). We hypothesized that SERT inhibition limited to early postnatal development (P5-P2I) via exposure to selective serotonin reuptake inhibitors (SSRIs) in mice would produce changes in serotonin system function and behavior different from those arising from constitutive SERT deficiency, which alters SERT function throughout life. We discovered that postnatal administration of the antidepressant escitalopram (ESC) but not fluoxetine results in a hyposerotonergic state during adulthood associated with reduced anxiety-related behavior in the elevated plus maze (EPM). This directly contrasts with the hyperserotonergic state (increased extracellular serotonin levels) and increased anxiety-like behavior in mice with lifelong reductions in Sert gene expression. Hyposerotonemia is accompanied by $5-\mathrm{HT}_{\text {IA }}$ autoreceptor hypersensitivity in mice exposed to postnatal ESC, while genetic SERT deficiency causes desensitization of $5-\mathrm{HT}_{\text {IA }}$ autoreceptors.

clear Plexiglas to ensure even light levels across all arms. The floor of the maze was constructed of a continuous piece of opaque Plexiglas. Mice were placed on the center platform facing a closed arm and allowed to explore the maze freely for $5 \mathrm{~min}$. The maze was cleaned with $70 \%$ ethanol and dried between mice. Behavior was videotaped and visually scored by trained observers blind to postnatal treatment or genotype. Parameters quantified included latency to first open arm entry, numbers of open arm four-paw arm entries, numbers of closed arm four-paw arm entries, open arm time, closed arm time, rears in the closed arms, and head dips from the center platform or open arms. Times in the open or closed arms were analyzed as a percentage of total arm time excluding time spent in the center platform of the maze.

\section{Open Field Test}

Locomotor activity in an open field was assessed using a three-point digital video tracking system and Viewer ${ }^{2}$ software (BIOBSERVE GmbH, Bonn, Germany). Open field arenas were $50 \mathrm{~cm} \times 50 \mathrm{~cm} \times 40 \mathrm{~cm}$ height. The center area 
was defined by a $22 \mathrm{~cm} \times 22 \mathrm{~cm}$ central square. Animals were considered to be in the center after the midpoint of the body entered the center area. Mice were placed in a corner of the open field and allowed to freely explore for $60 \mathrm{~min}$. Only the data for the first 30 min were used in the analyses. Total distance traveled $(\mathrm{cm})$ and the ratio of center distance to total distance was measured. Additionally, time spent exploring the center region was analyzed. Testing environments were thoroughly cleaned with $70 \%$ ethanol and allowed to dry between mice.

\section{Forced Swim Test}

This test was carried out as previously described with minor modifications (Porsolt et al, 1977; Shen et al, 2010). Briefly, each mouse was placed in a clear glass cylinder $(27 \mathrm{~cm}$ high $\times 13 \mathrm{~cm}$ diameter) containing room temperature water $\left(22 \pm 2{ }^{\circ} \mathrm{C}\right)$ at a depth of $15 \mathrm{~cm}$. Behavior was videotaped during 6-min swim sessions. Afterwards, mice were transferred to a warm environment while their fur dried before being returned to their home cages. Mice were retested under the same conditions $24 \mathrm{~h}$ later to assess the effects of repeated swim stress (Borsini et al, 1989; Porsolt et al, 1977), which is thought to alter depression-like behavior in SERT-deficient mice on a C57BL/6J background (Carroll et al, 2007). Cylinders were cleaned with $70 \%$ ethanol and refilled with fresh water between mice. Data were collected and analyzed in 1-min bins using FST High Throughput Forced Swim Test Analysis software (BIOBSERVE GmbH). Time spent immobile during the last $4 \mathrm{~min}$ of each $6 \mathrm{~min}$ trial was summed (Porsolt et al, 2001).

\section{Presynaptic Serotonin $_{1 \mathrm{~A}}\left(5-\mathrm{HT}_{1 \mathrm{~A}}\right)$ Receptor Function}

We investigated $5-\mathrm{HT}_{1 \mathrm{~A}}$ autoreceptors because this receptor subtype is critical for controlling serotonergic neurotransmission (Richer et al, 2002) and is implicated in antidepressant and anti-anxiety responses (Altieri et al, 2012; Altieri et al, 2013; Hjorth and Auerbach, 1994; Holmes et al, 2003b; Popa et al, 2010; Richardson-Jones et al, 2010; Rossi et al, 2008a; Rossi et al, 2008b; Sinton and Fallon, 1988). Agonists at $5-\mathrm{HT}_{1 \mathrm{~A}}$ receptors produce hypothermia in mice via a presynaptic mechanism (Li et al, 1999; Martin et al, 1992; Richardson-Jones et al, 2011). A randomized block design was used wherein all mice received three treatments in different orders with a 3-day separation between treatmenttesting days. Mice were injected with saline or the $5-\mathrm{HT}_{1 \mathrm{~A}}$ receptor agonist 8-hydroxy- $N, N$-dipropyl-2-aminotetralin (8-OH-DPAT; 0.1 or $0.4 \mathrm{mg} / \mathrm{kg}, \mathrm{sc}$, calculated as the free base and dissolved in saline at $0.1 \mathrm{mg} / \mathrm{ml}$ ) (Li et al, 1999; Popa et al, 2008). Adult body weights were recorded at this time. Mice were habituated to a rectal temperature probe one day prior to the first testing day (Physitemp Instruments, Clifton, NJ). Two baseline temperatures were recorded 20 and $10 \mathrm{~min}$ prior to injection. Core body temperatures were recorded in 10-min increments postinjection for $1 \mathrm{~h}$ and then again at 90 and $120 \mathrm{~min}$ after injection to verify that temperatures returned to baseline.

\section{Guide Cannula Implantation Surgery}

At 10-14 months of age and following behavior testing, mice were implanted unilaterally with a guide cannula for a
CMA/7 microdialysis probe (CMA/Microdialysis, Solna, Sweden) into the left ventral hippocampus in the CA3 region (coordinates relative to Bregma: AP $-2.8 \mathrm{~mm}, \mathrm{ML}$ $-3.5 \mathrm{~mm}, \mathrm{DV}-2.2 \mathrm{~mm}$ ) under isoflurane anesthesia. The cannula was held in place with dental resin (Bosworth Trim II, from Bosworth Company, Skokie, IL), which was secured to the skull with a stainless steel screw (Eicom-USA, San Diego, CA). Microdialysis experiments described below were performed 3-20 days after cannula implantation.

\section{Microdialysis and No-Net-Flux Protocols}

Probe insertion. At 1400-1500 hours, each subject was briefly (3-5 $\mathrm{min}$ ) anesthetized using isoflurane for insertion of a CMA/7 microdialysis probe (active membrane length $2 \mathrm{~mm}$; CMA/Microdialysis) into the guide cannula. Immediately after insertion, an aCSF solution $(147 \mathrm{mM} \mathrm{NaCl}$, $3.5 \mathrm{mM} \mathrm{KCl}, 1.0 \mathrm{mM} \mathrm{CaCl}, 1.0 \mathrm{mM} \mathrm{NaH} \mathrm{PO}_{4}, 2.5 \mathrm{mM}$ $\mathrm{NaHCO}_{3}, 1.2 \mathrm{MgCl}_{2}, \mathrm{pH} 7.3 \pm 0.03$ at room temperature) was continuously perfused through the probe at $3 \mu \mathrm{l} / \mathrm{min}$ for $30-60 \mathrm{~min}$ followed by a $1.1 \mu \mathrm{l} / \mathrm{min}$ flow rate for an additional $12-14 \mathrm{~h}$ to allow recovery from acute injuryrelated neurotransmitter release due to probe insertion.

Microdialysis. Male and female mice treated postnatally with saline, FLX, or ESC were used in experiments to determine the effects of 8-OH-DPAT on extracellular serotonin levels. At $0330-0400$ hours on the day after probe insertion, the flow rate of aCFS through the probe was increased to $3 \mu \mathrm{l} / \mathrm{min}$ for at least $30 \mathrm{~min}$ before collecting dialysate samples. Basal samples were collected in 6-min increments over the course of $2 \mathrm{~h}$, after which $1.2 \mu \mathrm{M}$ ESC was infused into the probe to increase local concentrations of extracellular serotonin (Hjorth et al, 1997; Tao et al, 2000). Samples were collected for another $2 \mathrm{~h}$. Subsequently, mice received a sc saline injection $(1 \mathrm{ml} / \mathrm{kg})$, and dialysate samples were collected for $1 \mathrm{~h}$. Each mouse then received increasing doses of 8 -OH-DPAT $(0.025,0.05,0.1,0.2$, and $0.4 \mathrm{mg} / \mathrm{kg}, \mathrm{sc}$ ), and dialysate samples were collected for an additional hour after each dose. Sampling times were $6 \mathrm{~min}$ throughout.

Dialysate samples were analyzed online continuously by high-performance liquid chromatography coupled to electrochemical detection (HTEC-500, Eicom-USA). Dialysates and standards were separated using a mobile phase composed of $96 \mathrm{mM} \mathrm{NaH}_{2} \mathrm{PO}_{4}, 3.8 \mathrm{mM} \mathrm{Na}_{2} \mathrm{HPO}_{4}, \mathrm{pH} 5.4,2.8 \%$ $\mathrm{MeOH}, 50 \mathrm{mg} / \mathrm{l} \mathrm{EDTA}-\mathrm{Na}_{2}$, and $500 \mathrm{mg} / \mathrm{l}$ sodium decanesulfonate in water purified by a Milli-Q Synthesis A10 system (EMD Millipore Corporation, Billerica, MA). The stationary phase was a PP-ODS II column $(4.6 \mathrm{~cm} \times 3 \mathrm{~mm}, 2-\mu \mathrm{m}$ particle size, Eicom-USA). There were no statistically significant differences between sexes, so microdialysis data from male and female mice within each postnatal treatment group were combined.

No-net-flux. Male and female mice treated postnatally with SSRIs and male SERT-deficient mice were used in experiments to determine the levels of extracellular serotonin in the ventral hippocampus. No-net-flux protocols were similar to previously published methods (Luellen et al, 2007; Mathews et al, 2004; Szapacs et al, 2004; Yang et al, 
2013) with the following modifications. At 0400-0500 hours on the day following probe insertion, the flow rate of aCSF was increased to $3 \mu \mathrm{l} / \mathrm{min}$ at least $30 \mathrm{~min}$ prior to dialysate sampling. Basal samples were collected over $2 \mathrm{~h}$. Subsequently, five concentrations of serotonin ranging from 2.5 to $50 \mathrm{nM}$ were perfused via the microdialysis probe using a programmable gradient infusion CMA/102 pump (CMA/ Microdialysis, Harvard Apparatus, Holliston, MA). Dialysates were collected for $90 \mathrm{~min}$ at each concentration of serotonin. Samples were collected in 6-min intervals and analyzed online continuously as described above.

Probe verification. After microdialysis experiments, mice were killed by cervical dislocation, and the brains were rapidly removed. The anterior portion of each brain, including the hippocampus, was placed in $7 \%$ paraformaldehyde phosphate buffer (PB), $\mathrm{pH} 7.3$ for $48-72 \mathrm{~h}$ at room temperature on a laboratory rotator. Brains were then transferred to a $30 \%$ sucrose-PB solution and stored at $-80^{\circ} \mathrm{C}$. Preserved brains were sectioned at $50 \mu \mathrm{m}$ using a cryostat and stained by cresyl violet. Probe locations were verified under a microscope.

\section{Autoradiography}

Mice were euthanized by cervical dislocation. Brains were rapidly removed and placed on wet ice for coronal sectioning. The anterior portion was reserved for microdialysis probe placement verification as described above. Posterior portions of the brains containing the dorsal raphe nucleus (DRN) and median raphe nucleus (MRN) were placed in cold $1 \times$ PBS (Gibco Life Technologies, Grand Island, NY) for $1 \mathrm{~min}$ and then frozen on powdered dry ice. Brains were stored at $-80^{\circ} \mathrm{C}$ until further processing.

A cryostat microtome (Leica CM1850, Leica Microsystems, Buffalo Grove, IL) was used to cut $20-\mu \mathrm{m}$ coronal sections (plates 68-70) (Paxinos and Franklin, 2001). Brain sections were mounted on gelatin-coated slides with two sections per slide, which allowed for duplicate determinations. Sections were then desiccated for $18 \mathrm{~h}$ at $4{ }^{\circ} \mathrm{C}$ and maintained at $-80{ }^{\circ} \mathrm{C}$ for storage. Quantitative autoradiography for $5-\mathrm{HT}_{1 \mathrm{~A}}$ receptor binding, $5-\mathrm{HT}_{1 \mathrm{~A}}$ agoniststimulated GTP $-\gamma$ S binding, and SERT binding were carried out using previously published methods (Burke et al, 2013; Hensler, 2002; Licht et al, 2010; Rossi et al, 2008a).

$5-\mathrm{HT}_{1 \mathrm{~A}}$ receptor binding was assessed in the DRN and MRN using the radiolabeled antagonist $\left[{ }^{3} \mathrm{H}\right]$ WAY- 100635 . Slide-mounted sections were thawed, desiccated at $4{ }^{\circ} \mathrm{C}$ for $1 \mathrm{~h}$ and preincubated $\left(30 \mathrm{~min}, 30^{\circ} \mathrm{C}\right)$ in assay buffer (170 mM Tris-HCl, $\mathrm{pH} 7.6$ ). Sections were then placed in assay buffer with $2 \mathrm{nM}\left[{ }^{3} \mathrm{H}\right] \mathrm{WAY}-100635$ and incubated for $60 \mathrm{~min}$ at room temperature. Adjacent sections were incubated in assay buffer containing $\left[{ }^{3} \mathrm{H}\right]$ WAY-100635 and cold NAN190 $(1 \mu \mathrm{M})$, to determine nonspecific binding. Sections were then washed $(2 \times 5 \mathrm{~min})$ in ice-cold $170 \mathrm{mM}$ Tris- $\mathrm{HCl}$ buffer ( $\mathrm{pH}$ 7.6), dipped in ice-cold deionized water, and dried on a slide warmer. Slides were exposed to Kodak BioMax MR film for 9 weeks. Digitized autoradiograms were analyzed using ImageJ, version $1.42 \mathrm{q}$ (National Institutes of Health, Bethesda, MD) (Burke et al, 2013). Tissue sections were stained with thionin, and the brain areas were identified using a mouse brain atlas (Paxinos and Franklin, 2001). Specific binding, expressed as fmol/mg protein, was calculated by subtracting nonspecific binding from total binding for each brain region analyzed.

For autoradiography of 8-OH-DPAT-stimulated $\left[{ }^{35} \mathrm{~S}\right] \mathrm{GTP} \gamma \mathrm{S}$ binding, slide-mounted sections were equilibrated $(10 \mathrm{~min}$, $\left.25^{\circ} \mathrm{C}\right)$ in assay buffer (50 mM HEPES, pH 7.4, with $3 \mathrm{mM}$ $\mathrm{MgCl}_{2}, 2 \mathrm{mM}$ EGTA, $100 \mathrm{mM} \mathrm{NaCl}$, and $2 \mathrm{mM}$ dithiothreitol). Sections were preincubated $\left(15 \mathrm{~min}, 25^{\circ} \mathrm{C}\right)$ in assay buffer containing guanosine diphosphate (GDP) $(2 \mathrm{mM})$ and the adenosine A1 receptor antagonist, 1,3-dipropyl-8-cyclopentylxanthine (DPCPX) $(1 \mu \mathrm{M})$ and then incubated $(60 \mathrm{~min}$, $\left.25^{\circ} \mathrm{C}\right)$ in assay buffer containing GDP $(2 \mathrm{mM})$, DPCPX $(1 \mu \mathrm{M})$, and $40 \mathrm{pM}\left[{ }^{35} \mathrm{~S}\right] \mathrm{GTP} \gamma \mathrm{S}$, either in the absence or presence of 8-OH-DPAT (15 nM or $1 \mu \mathrm{M})$. Basal $\left[{ }^{35} \mathrm{~S}\right] \mathrm{GTP} \gamma \mathrm{S}$ binding was determined in the absence of 8-OH-DPAT. Nonspecific $\left[{ }^{35} \mathrm{~S}\right] \mathrm{GTP} \gamma \mathrm{S}$ binding was assessed in the absence of 8-OH-DPAT and the presence of $10 \mu \mathrm{M}$ GTP $\gamma \mathrm{S}$. Sections were washed and processed as described above. Slides were exposed to Kodak BioMax MR film for $48 \mathrm{~h}$. Nonspecific binding of $\left[{ }^{35} \mathrm{~S}\right] \mathrm{GTP} \gamma \mathrm{S}$ was subtracted from basal binding and binding in the presence of an agonist. Agoniststimulated specific binding was expressed as the percentage above basal.

SERT densities were determined in the DRN and MRN using $\left[{ }^{3} \mathrm{H}\right]$ citalopram binding. Slide-mounted sections were thawed and desiccated at $4{ }^{\circ} \mathrm{C}$ for $1 \mathrm{~h}$ and then equilibrated $\left(15 \mathrm{~min}, 25^{\circ} \mathrm{C}\right)$ in assay buffer $(50 \mathrm{mM}$ Tris- $\mathrm{HCl}, 120 \mathrm{mM}$ $\mathrm{NaCl}$, and $5 \mathrm{mM} \mathrm{KCl}, \mathrm{pH}$ 7.4). Sections were incubated in the same buffer containing $6.5 \mathrm{nM}\left[{ }^{3} \mathrm{H}\right]$ citalopram $\left(\sim 8 \times K_{\mathrm{D}}\right)$ for $60 \mathrm{~min}$ at $25^{\circ} \mathrm{C}$. Nonspecific binding was determined in the presence of $1 \mu \mathrm{M}$ paroxetine. Sections were washed $(2 \times$ $5 \mathrm{~min}$ ) in ice-cold $50 \mathrm{mM}$ Tris buffer ( $\mathrm{pH} 7.4)$, immersed in ice-cold deionized water, and dried on a slide-warmer. Sections were exposed to Kodak Biomax MR film for 5 weeks to develop autoradiograms, which were analyzed using ImageJ, version $1.42 \mathrm{q}$ (National Institutes of Health).

\section{Chemicals}

S- $(+)$-Citalopram oxalate and fluoxetine hydrochloride were obtained from BioTrend Chemicals (Destin, FL). ( \pm )-8Hydroxy-DPAT hydrobromide was purchased from Sigma (St Louis, MO) for administration to mice and from Tocris Bioscience (Minneapolis, Minnesota) for autoradiography. Sodium phosphate monobasic $\left(\mathrm{NaH}_{2} \mathrm{PO}_{4}\right)$, sodium phosphate dibasic $\left(\mathrm{Na}_{2} \mathrm{HPO}_{4}\right)$, NAN $190 \mathrm{HBr}$, GDP (disodium salt), and ethylenediaminetetraacetic acid disodium salt $\left(\right.$ EDTA- $\mathrm{Na}_{2}$ ) were purchased from Sigma. Methanol was from EMD Millipore, and sodium decanesulfonate was from TCI America (Portland, OR). Sterile endotoxin-free saline was purchased from Anawa Trading (Wangen, Switzerland). GTP $\gamma$ S (tetralithium salt) was purchased from Roche Applied Science (Indianapolis, Indiana). WAY-100635 maleate and DPCPX were purchased from Tocris Bioscience. Paroxetine $\mathrm{HCl}$ was from Shanco International (Hazlet, New Jersey). $\left[{ }^{3} \mathrm{H}\right]$ WAY-100635 (85.3 Ci/mmol), $\left[{ }^{35} \mathrm{~S}\right] \mathrm{GTP} \gamma \mathrm{S} \quad(1250 \mathrm{Ci} /$ $\mathrm{mmol})$, and $\left[{ }^{3} \mathrm{H}\right]$ citalopram $(84.5 \mathrm{Ci} / \mathrm{mmol})$ were purchased from PerkinElmer/NEN (Boston, Massachusetts).

\section{Statistics}

Periadolescent behavior data were analyzed by two-way analysis of variance (ANOVA), with sex and postnatal 
treatment as independent variables. Unhandled and saline-treated SERT $+I+$ mice were compared using Student's unpaired $t$-tests. No differences between these groups occurred for any variable; therefore, data from the saline-treated and unhandled groups were combined and compared with ESC-treated mice by $t$-tests. Saline-treated mice were also directly compared with ESC-treated mice.

Adult behavior data were analyzed by factor analysis, which is a statistical method that reduces a large set of observed variables to a smaller number of unobserved (latent) factors to account for correlations among the observed variables (Brigman et al, 2009; Holmes and Rodgers, 1998). Where necessary, mathematical signs were reversed, ie, reduced time/entries and head dips in the open arms reflect an increase in anxiety so the signs for these data were reversed. Prior to factor analysis, behavior data for each variable were normalized to same-sex/same-age/ treatment or genotype control groups. Standard score normalization was applied using the equation $z=(x-\mu)$ / $\sigma$, where $x$ is the individual score, $\mu$ is the mean for the appropriate control group, and $\sigma$ is the control group SD (Guilloux et al, 2011). Saline-treated SERT $+/+$ mice were controls for postnatal SSRI-treated groups. Unhandled SERT $+I+$ mice were controls for genotype groups. Global behavioral phenotypes were assessed using 10 preselected, non-redundant variables by orthogonal rotation (varimax). Behavior data were used for factor analysis without removing outliers. Scree plots were used to extract factor matrices (eigenvalues >0.7). Standard scores for variables that loaded together for each factor (loadings >0.3) were combined to create an integrated score and were weighted proportionally to variable loadings. Individual group comparisons were by unpaired two-tailed $t$-tests according to a priori hypotheses. Prior to comparing groups, $4 />1200$ data points were removed as they were $> \pm 3$ SDs from the group means.

Body weight, temperature, and 8-OH-DPAT microdialysis data were analyzed by two-way ANOVA, with genotype or postnatal SSRI treatment and age or dose as independent variables. With the exception of a single temperature data point that was $> \pm 3 \mathrm{SD}$ from the mean, no data were removed prior to analysis. For $\left[{ }^{3} \mathrm{H}\right] \mathrm{WAY}-100635$ and $\left[{ }^{3} \mathrm{H}\right]$ citalopram binding, data were analyzed by two-way ANOVA with brain region and postnatal antidepressant treatment as independent variables. For $\left[{ }^{35} \mathrm{~S}\right] \mathrm{GTP}-\gamma \mathrm{S}$ binding, the independent variables were 8-OH-DPAT concentration and postnatal antidepressant treatment. For all two-way ANOVAs, main effects were analyzed only in cases of nonsignificant interaction terms. In cases of significant interactions, data were analyzed by one-way ANOVA at each age or 8-OH-DPAT dose to determine simple effects.

For no-net-flux microdialysis, data for each treatment group were regressed with perfused serotonin concentrations $\left(C_{\text {in }}\right)$ on the $x$ axis and the difference between perfused serotonin and dialysate serotonin concentrations $\left(C_{\text {in }}-C_{\text {out }}\right)$ on the $y$ axis. Intercepts of regression lines with the $x$ axis were used to estimate extracellular serotonin levels corrected for in vivo extraction fraction. Data were compared group-wise using a nonparametric Kruskal-Wallis test due to non-Gaussian distributions followed by Dunnett's multiple comparisons.

Statistics were computed using the GraphPad Prism v.6 (GraphPad, La Jolla, CA) or SAS Statistical Software v.9.3 (SAS Institute, Cary, NC). All data are expressed as means \pm SEMs, with $P<0.05$ considered statistically significant.

\section{RESULTS}

\section{Adolescent Anxiety-Related Behavior After Early Postnatal ESC Exposure}

Initially, we investigated the behavior in adolescent mice following developmental exposure to the commonly prescribed antidepressant ESC (Lindsley, 2012). Anxiety-like behavior was assessed in the elevated plus maze and open field. These widely used tests measure conflict-avoidance behavior and responses to novelty in rodents. Specific aspects of these tests also enable evaluation of activity levels and exploratory behavior. Depression-related behavior was examined in the forced swim test. Mice with normal SERT expression (wild type) were treated with ESC from P5 to P21. At P50, female and male ESC-treated mice exhibited increased time and numbers of entries in the open arms of the elevated plus maze compared with saline-treated and unhandled mice indicative of reduced anxiety-related behavior (Figure 2a and b). Anxiety-related behavior and total distance traveled in the open field and depressive-like behavior in the forced swim test were not different between periadolescent ESC-treated, saline-treated, and unhandled
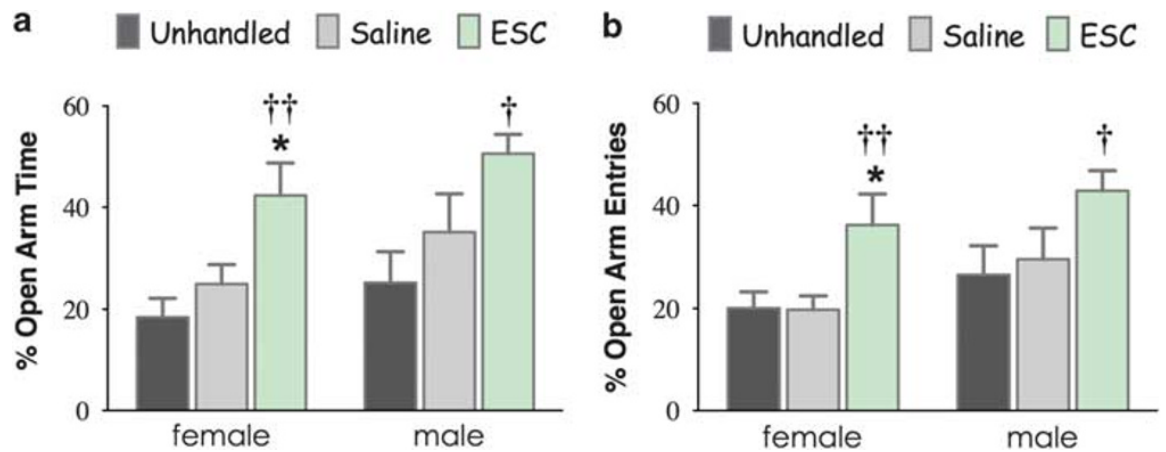

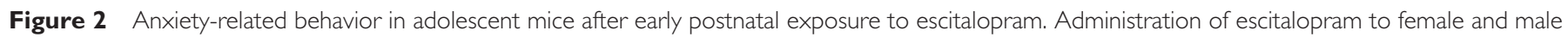

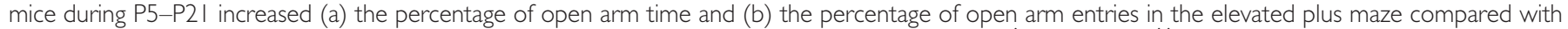
saline-treated and unhandled mice during periadolescence (P50). ${ }^{*} P<0.05$ vs unhandled control; ${ }^{\dagger} P<0.05$ and ${ }^{\dagger \dagger} P<0.0$ I vs saline-treated control. 
mice (Supplementary Figure S1). Late adolescent body weights at P60 were also not significantly different across groups (Supplementary Figure S2).

\section{Adult Behavior After Postnatal Antidepressant Exposure vs SERT Deficiency}

We next investigated behavior in a large cohort of adult mice following postnatal exposure to ESC. Separate groups of mice were exposed to FLX to compare two widely prescribed SSRIs (Figure 3a). Mice treated with saline during P5-P21 were controls for SSRI-exposed mice. To compare the effects of constitutive SERT deficiency, behavior was analyzed in untreated wild-type mice $(\mathrm{SERT}+I+)$ and mice with complete $(\mathrm{SERT}-I-)$ and partial (SERT $+I-$ ) loss of SERT. The latter are models of reduced SERT expression associated with low-expressing human SLC6A4 gene variants (Hu et al, 2006; Murphy and Lesch, 2008b). Group sizes $(N=13-28 \mathrm{mice} / \mathrm{sex})$ are detailed in Supplementary Table S1. Assessments of anxiety, depressive, locomotor, and exploratory behaviors were made beginning at 3 or 10 months of age in separate cohorts of animals (Figure 3a). Raw data are summarized in Supplementary Table S2.

Together, a large number of variables are associated with the elevated plus maze, open field, and forced swim

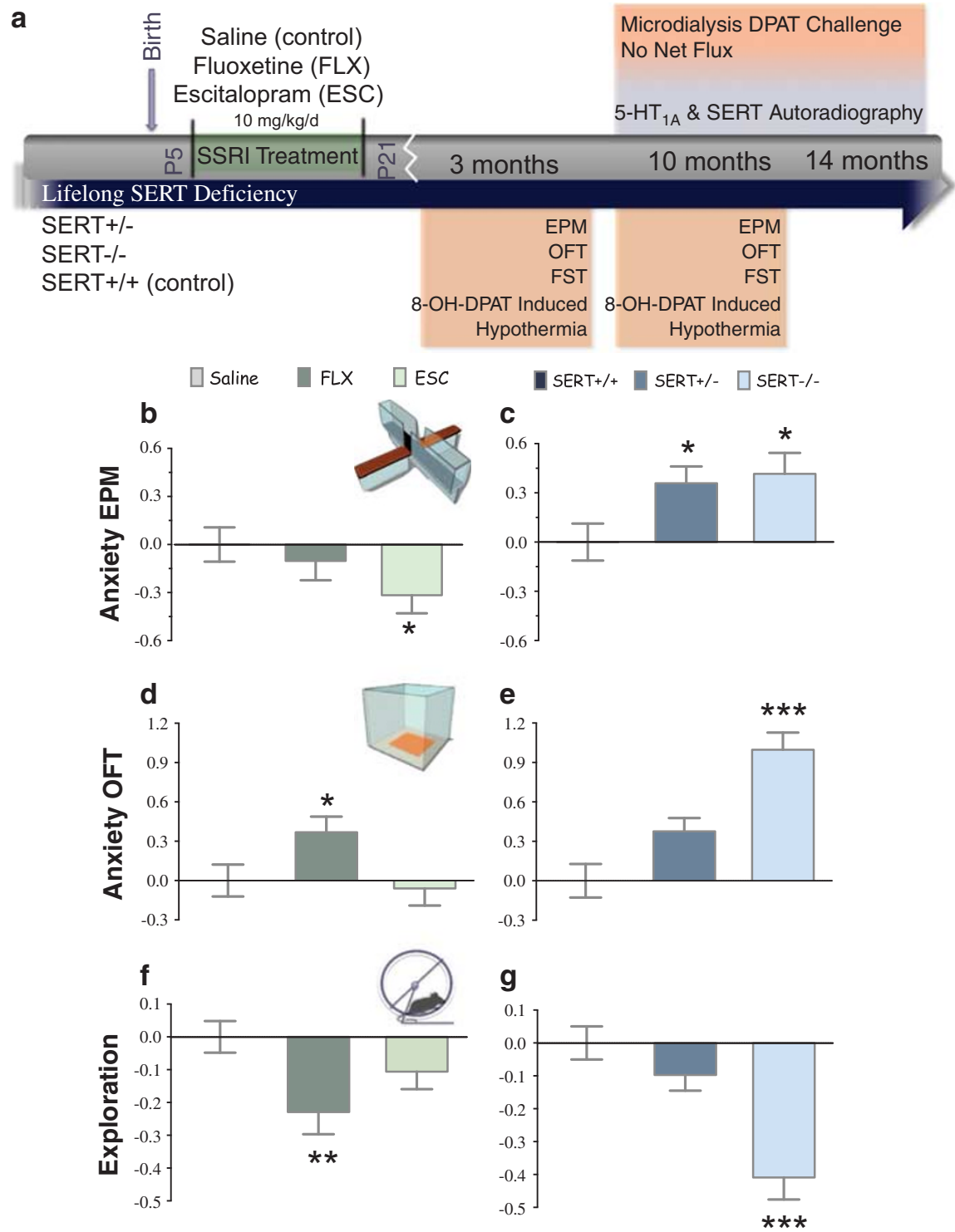

Figure 3 Anxiety-related and exploratory behavior in postnatal SSRI-exposed vs SERT-deficient mice. (a) The timeline shows the treatment paradigm for postnatal SSRI administration and the timing of experimental testing for adult SERT-deficient and SSRI-exposed mice. For global behavior analysis, standard score normalization was applied with respect to age and sex for each variable to combine data with different dynamic ranges and directions of change (Guilloux et al, 20 I I). Standard scores were weighted by coefficients proportional to their loadings in the factor analysis (Supplementary Table S3). (b and c) Latency to first open arm entry, open arm time, the percentage of open arm entries, and head dips in the elevated plus maze loaded on a single factor ('Anxiety EPM'). ( $d$ and e) The open field anxiety-like parameters, center time, and ratio of center to total distance traveled loaded on a separate factor ('Anxiety OFT'). ( $\mathrm{f}$ and g) Exploration (factor 3 ) was determined by total arm entries and rears in the elevated plus maze and total distance traveled in the open field. Group sizes are listed in Supplementary Table SI. $* P<0.05$, $* * P<0.0$ I, and ${ }^{*} * * P<0.00$ I vs postnatal saline-treated or SERT $+I+$ mice. 
tests. To reduce bias in interpreting the entire data set resulting from these tests, we employed factor analysis (Brigman et al, 2009; Holmes and Rodgers, 1998) to produce unbiased global behavioral profiles (Gross et al, 2000). Data from 10 variables collected from $>400$ mice were combined for analysis. Three factors clearly emerged accounting for the majority ( $>99 \%$ ) of the common variance shared by the variables in the model (Supplementary Table S3). Open arm latency, open arm time, the percentage of open arm entries, and head dips in the open arms of the elevated plus maze loaded together on factor 1, referred to as 'Anxiety EPM'. This factor encompassed measures of anxiety-related behavior in the elevated plus maze and accounted for $47 \%$ of the common variance. Center time and the ratio of center/total distance traveled in the open field, which are also considered measures of anxiety-like behavior, loaded together on a separate factor referred to as 'Anxiety OFT' and accounted for $35 \%$ of the common variance. Total arm entries and the numbers of rears in the closed arms of the elevated plus maze, and total distance traveled in the open field, which are measures of exploration, loaded on a third factor termed 'Exploration', which accounted for $18 \%$ of the common variance. Depressionrelated behavior, assessed by immobility in the forced swim test, did not differ with respect to postnatal SSRI treatment or constitutive SERT deficiency and did not load with any factor (Supplementary Table S3). Alternate factor analyses within genotype or postnatal treatment groups or between sexes identified similar factors (Supplementary Tables S4-S7).

The three factors revealed contrasting patterns of behavior between SSRI-treated mice and SERT-deficient mice and, furthermore, between mice treated postnatally with ESC $v s$ FLX. Similar to periadolescence, in adulthood, postnatal ESC exposure was associated with reduced anxiety-related behavior in the elevated plus maze (Anxiety EPM; $P<0.05$; Figure $3 \mathrm{~b}$ ). Also similar to periadolescence, adult mice exposed postnatally to ESC showed no changes in anxiety-related behavior in the open field (Anxiety OFT; Figure $3 \mathrm{~d}$ ) or exploratory behavior (Figure 3f). In contrast to developmental ESC exposure, adult SERT $+/-$ and SERT $-I-$ mice exhibited increased anxiety-related behavior in both anxiety domains (Anxiety EPM; $P<0.05$; Figure 3c; Anxiety OFT; $P<0.05$ SERT $+/-; P<0.001$ SERT $-/-$; Figure 3e). Exploratory behavior was reduced in SERT $-1-$ mice $(P<0.001$; Figure $3 g)$. As adults, postnatal FLX-exposed mice were different from both postnatal ESC-exposed and SERT-deficient mice in the Anxiety EPM domain showing no change in behavior in the elevated plus maze (Figure $3 \mathrm{~b}$ ). By contrast, mice exposed to FLX during early development showed increased anxietyrelated behavior in the open field similar to SERT-deficient mice $(P<0.05$; Figure 3d). Moreover, postnatal FLX resulted in reduced exploration $(P<0.01$; Figure $3 f)$, which was also similar to SERT $-/$ - mice.

To determine whether these behavioral effects were accompanied by altered growth, we examined weight gain during the early postnatal and adult periods (Supplementary Figures S3 and S4). Developmental exposure to ESC or FLX caused long-term decreases in body weight, changes that were not recapitulated in SERTdeficient mice.

\section{Contributions of $5-\mathrm{HT}_{1 \mathrm{~A}}$ Autoreceptors}

To uncover the potential mechanisms underlying divergent anxiety-related phenotypes, we investigated $5-\mathrm{HT}_{1 \mathrm{~A}}$-autoreceptor function. Leonardo and colleagues identified presynaptic $5-\mathrm{HT}_{1 \mathrm{~A}}$ receptors as key regulators of anxietyrelated behavior, particularly during developmental time frames (Richardson-Jones et al, 2011). Moreover, previous studies suggested divergent adaptive responses of $5-\mathrm{HT}_{1 \mathrm{~A}}$ autoreceptors to constitutive loss of SERT (Li et al, 1999) vs P5-P19 ESC administration (Popa et al, 2008). To determine $5-\mathrm{HT}_{1 \mathrm{~A}}$-autoreceptor responsiveness, we measured hypothermia in response to the $5-\mathrm{HT}_{1 \mathrm{~A}}$ agonist 8 -OH-DPAT (Richardson-Jones et al, 2011).

In young adult mice treated postnatally with SSRIs, lower $(0.1 \mathrm{mg} / \mathrm{kg})$ and higher $(0.4 \mathrm{mg} / \mathrm{kg})$ dose of $8-\mathrm{OH}-\mathrm{DPAT}$ significantly reduced body temperature (Supplementary Figures S5A and C and S6A and C). Notably, mice exposed to developmental ESC showed potentiated responses to the higher dose of 8-OH-DPAT compared with saline-exposed mice $(P<0.01)$. Both doses of 8 -OH-DPAT significantly reduced body temperature in 3-month-old SERT $+I+$ and SERT $+I-$ mice (Supplementary Figures S5B and D and $\mathrm{S} 6 \mathrm{~B}$ and $\mathrm{D})$. By contrast, SERT $-I-$ mice showed no change in body temperature in response to either dose of 8-OH-DPAT $(P<0.001)$. At 10 months of age, male mice treated postnatally with ESC responded to low- and highdose 8-OH-DPAT in a potentiated manner compared with saline- and FLX-treated mice (Figure 4a and c; Supplementary Table S8). Aging female mice exposed to antidepressants showed no differences in hypothermia compared with saline-exposed mice; whereas SERT - Imice of both sexes showed no change in body temperature after either dose of 8-OH-DPAT (Figure $4 \mathrm{~b}$ and $\mathrm{d}$ and Supplementary Figure S7).

In addition to body temperature, which is modulated by serotonergic projections to the hypothalamus, we investigated $5-\mathrm{HT}_{1 \mathrm{~A}}$-autoreceptor-mediated suppression of extracellular serotonin levels in the ventral hippocampus, a brain region important for processing emotionally salient information. We administered 8-OH-DPAT (0.025-0.4 mg/kg) to freely moving mice and measured changes in hippocampal extracellular serotonin by microdialysis. Early-life ESC exposure was associated with potentiated extracellular serotonin responses after all doses of 8-OH-DPAT at 10 months of age (Figure 4e; Supplementary Table S8). Reductions in serotonin levels in ESC-exposed mice were $30 \%$ greater than those in postnatal saline-exposed mice. Only the lowest dose of 8-OH-DPAT produced a potentiated decrease in extracellular serotonin in postnatal FLXexposed mice.

Autoradiography was carried out to investigate whether changes in 5- $\mathrm{HT}_{1 \mathrm{~A}}$-autoreceptor expression and/or G-protein coupling accompanied presynaptic 5- $\mathrm{HT}_{1 \mathrm{~A}}$ supersensitivity in postnatal ESC-treated mice. At 10-14 months of age, no differences in $\left[{ }^{3} \mathrm{H}\right]$ WAY-100635 binding or 8-OH-DPAT-stimulated $\left[{ }^{35} \mathrm{~S}\right] \mathrm{GTP} \gamma \mathrm{S}$ binding with respect to postnatal SSRI treatment were observed in the DRN or the MRN (Figure 4f; Supplementary Figure S8; Supplementary Table S8). These brain regions contain $5-\mathrm{HT}_{1 \mathrm{~A}}$ autoreceptors located on serotonin neurons projecting rostrally to the hypothalamus and ventral hippocampus (McQuade and Sharp, 1997). 
a
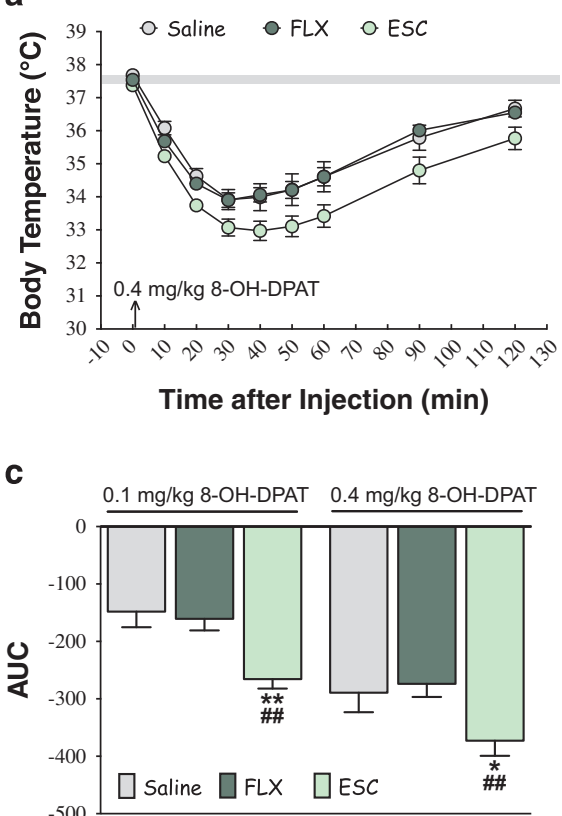

e

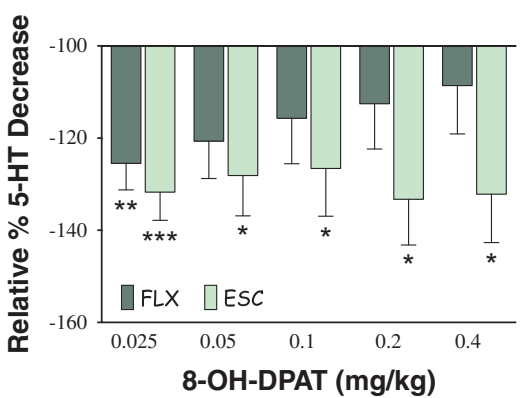

b

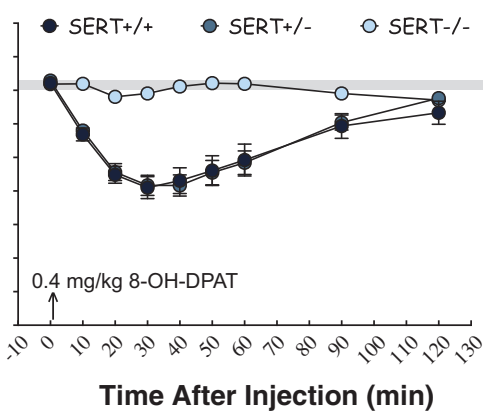

d

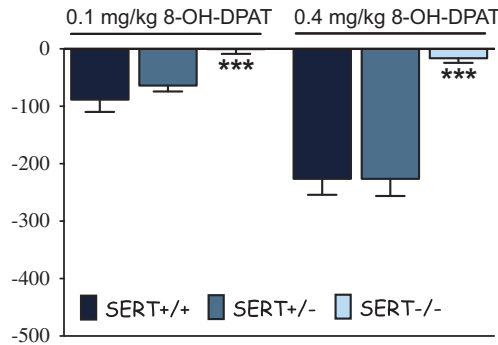

f

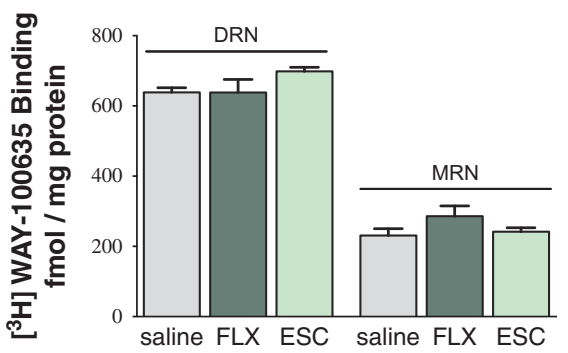

Figure 4 Serotonin-IA autoreceptor function and expression in postnatal SSRI-exposed vs SERT-deficient mice in late adulthood. (a and b) Time courses show changes in body temperature associated with administration of $0.4 \mathrm{mg} / \mathrm{kg} 8$-OH-DPAT to I0-month-old male postnatal SSRI-exposed and SERTdeficient mice. Gray-shaded horizontal bars represent mean body temperatures \pm SEMs for saline challenge across postnatal treatment groups or genotypes. (c and d) Potentiated hypothermia after $0.1 \mathrm{mg} / \mathrm{kg}$ or $0.4 \mathrm{mg} / \mathrm{kg} 8-\mathrm{OH}$-DPAT in 10 -month-old male mice exposed to postnatal ESC is indicated by increased areas under the curve. Conversely, a complete absence of thermal response after both doses of 8-OH-DPAT was observed in I0-month-old male SERT - I - mice. (e) Percentage of decreases in extracellular serotonin levels in the ventral hippocampus of freely moving I0-I4-month-old postnatal SSRI-exposed mice in response to 8-OH-DPAT challenge relative to decreases occurring in postnatal saline-treated mice. (f) Specific binding of $\left.{ }^{3} \mathrm{H}\right] \mathrm{WAY}$ 100635 in the dorsal raphe nucleus (DRN) or medial raphe nucleus (MRN) with respect to postnatal SSRI administration. For temperature and microdialysis data, $N=11$, I6, and 17 for postnatal saline-, FLX-, and ESC-treated mice, respectively, and $N=13$, 19 , and 12 for SERT $+1+$, SERT + / - , and SERT - I mice, respectively. For autoradiography, $N=3-5$ mice/group. For hypothermia data, $* P<0.05$ and $* * P<0.01$ vs saline-treated mice, $\# \# P<0.01$ vs FLX-treated mice, and $* * * P<0.001$ vs SERT $+1+$ mice. For microdialysis data, $* P<0.05$, ${ }^{*} * P<0.01$, and $* * * P<0.00$ I vs postnatal saline-treated mice administered the same dose of 8-OH-DPAT.

\section{Hippocampal Serotonin Transmission}

Divergent adaptation of $5-\mathrm{HT}_{1 \mathrm{~A}}$-autoreceptor function in postnatal SSRI-treated $v s$ SERT-deficient mice suggested underlying differences in serotonin neurotransmission. Somatodendritic $5-\mathrm{HT}_{1 \mathrm{~A}}$ receptors control serotonin release, and the sensitivity/function of these receptors is reciprocally regulated by extracellular serotonin levels (Altieri et al, 2013). No-net-flux microdialysis was used to quantify extracellular serotonin in the ventral hippocampus in the two models of SERT disruption (Mathews et al, 2004; Yang et al, 2013). We found significant reductions in extracellular serotonin concentrations 10-14 months after postnatal exposure to ESC compared with saline- or FLX-exposed mice $(P<0.05$; Figure 5a and c; Supplementary Table S8). Conversely, SERT - I - mice showed elevated hippocampal extracellular serotonin compared with SERT $+I+$ mice at this age $(P<0.001$; Figure $5 \mathrm{~b}$ and $\mathrm{d}$; Supplementary Table S8). Lesser magnitude increases in hippocampal extracellular serotonin were observed in SERT $+I-$ mice $(P<0.05$; Figure $5 \mathrm{~b}$ and $\mathrm{d}$ ). Mice receiving postnatal ESC also showed reduced basal dialysate serotonin levels $(P<0.05)$, whereas SERT $+I-\quad(P<0.01)$ and SERT $-I-$ mice $(P<0.001)$ showed increased dialysate serotonin. Dialysate serotonin levels for postnatal saline-, FLX-, and ESC-treated mice were $1.1 \pm 0.3 \mathrm{nM}, 0.77 \pm 0.09 \mathrm{nM}$, and $0.58 \pm 0.05 \mathrm{nM}$, respectively. 
a

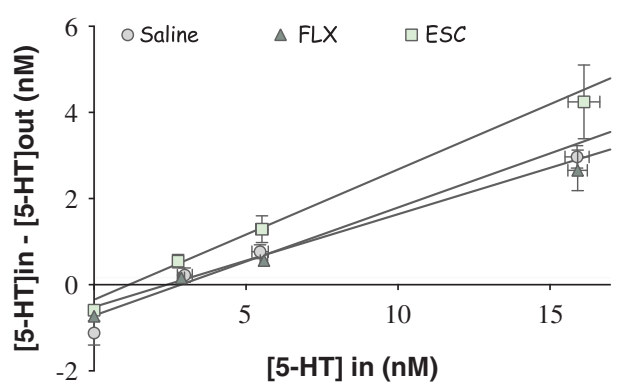

C

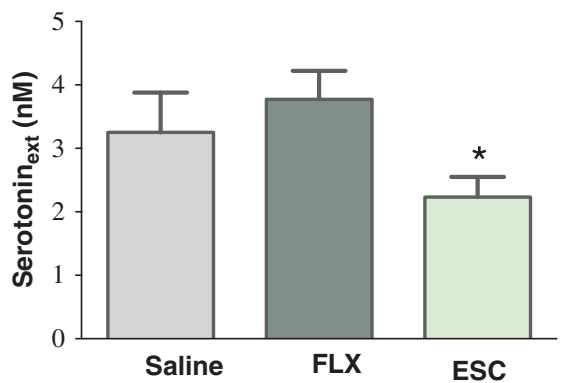

e

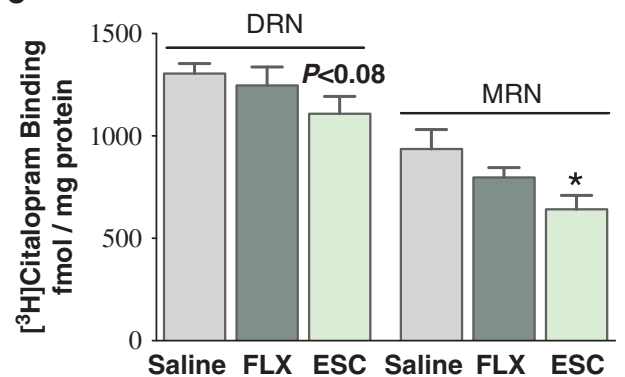

b

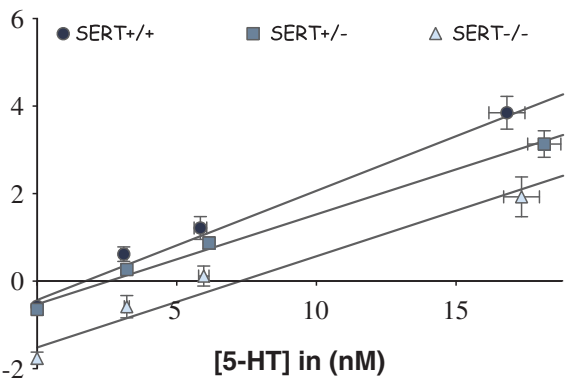

d

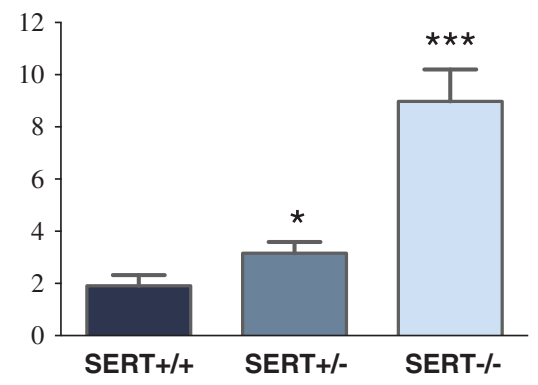

f

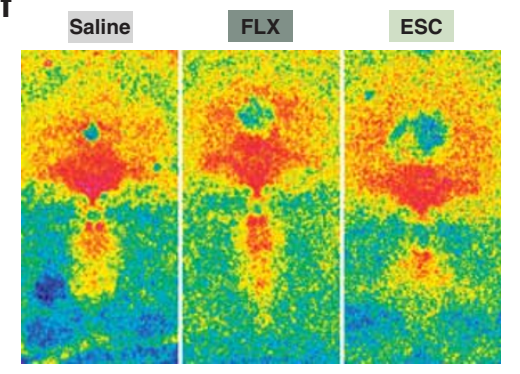

Figure 5 Extracellular serotonin concentrations and serotonin transporter expression. (a and b) Linear regression (no-net-flux) analysis was performed on different concentrations of serotonin perfused into microdialysis probes $\left(C_{\text {in }}\right)$ minus dialysate serotonin concentrations $\left(C_{\text {out }}\right)(y$ axis $)$ vs $C_{\text {in }}(x$ axis). Intercepts ( $x$ axis) were used to estimate extracellular serotonin levels in ventral hippocampus corrected for in vivo extraction fraction. Error bars are too small to be pictured in some cases. (c and d) Extracellular serotonin was reduced in postnatal ESC-exposed mice compared with postnatal saline-exposed mice at I014 months of age. By contrast, extracellular serotonin was elevated in SERT $+/$ - and SERT $-/-$ mice vs SERT + / + mice. Extracellular serotonin levels were $3.3 \pm 0.6 \mathrm{nM}, 3.8 \pm 0.5 \mathrm{nM}$, and $2.2 \pm 0.3 \mathrm{nM}$ in saline- $(N=15)$, FLX- $(N=17)$, and ESC-treated $(N=19)$ mice, respectively. Mean extracellular serotonin levels for SERT $+1+(N=14)$, SERT $+/-(N=19)$, and SERT $-/-(N=15)$ mice were $1.9 \pm 0.4 \mathrm{nM}, 3.2 \pm 0.4 \mathrm{nM}$, and $9.0 \pm 1.2 \mathrm{nM}$, respectively. (e and f) Total SERT binding was reduced in the median raphe nucleus (MRN) in postnatal ESC-treated mice $(N=4-5)$. Representative autoradiograms are shown for each treatment group. $* P<0.05$ vs postnatal saline-treated mice or SERT $+/+$ mice, and $* * P<0.0$ I and $* * * P<0.00$ I vs $\mathrm{SERT}+1+$ mice.

For SERT $+/+$, SERT $+I-$, and SERT $-I-$ mice, dialysate serotonin levels were $0.58 \pm 0.02 \mathrm{nM}, 0.65 \pm 0.01 \mathrm{nM}$, and $1.8 \pm 0.1 \mathrm{nM}$, respectively.

We investigated whether increased SERT levels might underlie hyposerotonemia and supersensitive $5-\mathrm{HT}_{1 \mathrm{~A}}$ autoreceptors in postnatal ESC-treated mice. On the contrary, $\left[{ }^{3} \mathrm{H}\right]$ citalopram binding to SERT was decreased by $30 \%$ in the MRN of 10-14 month-old mice treated postnatally with ESC $(P<0.05$; Figure 5e and f; Supplementary Table S8). There was a trend toward decreased SERT binding in the DRN of these mice $(-15 \% ; P<0.08)$.

\section{DISCUSSION}

We conclude that early exposure to the SSRI ESC causes a protracted hyposerotonergic state associated with reduced anxiety-related behavior. In contrast, constitutive SERT deficiency is defined by a persistent hyperserotonergic state underlying heightened anxiety (Figure 1a). Early exposure to the SSRI fluoxetine produced some but not all features associated with constitutive SERT deficiency. Altered behavior in FLX-exposed mice was not accompanied by changes in serotonergic transmission during late adulthood and thereby differed from early ESC exposure and SERT deficiency. When considered together, these findings support a role for serotonin neurotransmission in modulating adult anxietyrelated behavior. They suggest that serotonergic tone can be modified during early development by environmental and genetic factors. Moreover, anxiety-related behavior along a normal adult continuum appears to be maintained by persistent variations in serotonin transmission.

Studies dating back to the early 1980s identified a critical period in rodent development where antidepressants that 
inhibit SERT were found to cause lasting changes in emotion-related behavior (Ansorge et al, 2004; Mirmiran et al, 1981; Popa et al, 2008; Vogel et al, 1990). Only recently, however, were phenotypes associated with SERT inhibition limited to early postnatal periods (Ansorge et al, 2008; Ansorge et al, 2004; Popa et al, 2008) postulated to be similar to phenotypes manifested by SERT-deficient mice (Holmes et al, 2003b; Joeyen-Waldorf et al, 2009; Kalueff et al, 2007). Although some aspects of these two models may resemble one another, the present findings indicate that similarities disappear when anxiety-related behavior and serotonin neurotransmission are focused on.

In rodents, anxiety-like behavior is most often assessed by open arm behavior in the elevated plus maze (Walf and Frye, 2007) and activity in the center of the open field. Mice with reduced SERT expression consistently display increased anxiety-related behavior in these domains (Holmes et al, 2003a; Holmes et al, 2003b; Joeyen-Waldorf et al, 2009; Kalueff et al, 2007). In previous reports on adult mice treated postnatally with FLX or ESC, open arm parameters were not altered (Ansorge et al, 2008; Ansorge et al, 2004; Popa et al, 2008). These prior studies were conducted in mice on different background strains from the strain used here. Notably, SERT-deficient mice on an S129 background have high baseline anxiety that precludes geneassociated (Holmes et al, 2003a) and, possibly, postnatal SSRI exposure-associated differences in anxiety-related behavior from being detected. Additionally, elevated plus maze testing conditions vary across studies. For example, Ansorge et al (2008) tested mice during the light phase under bright light, whereas mice for the present study underwent elevated plus maze testing during the dark phase under dim lighting conditions. Similar to strain considerations, testing conditions can preclude differences in behavior from being detected. For example, the reduced anxiety-related phenotype observed here in postnatal ESCtreated mice might manifest only during higher activity dark-phase periods or be inhibited by bright lighting conditions such that modest drug-related effects are not observed.

Another finding of this study is that in mice anxietyrelated behavior in the elevated plus maze is qualitatively different from anxiety-related behavior in the open field as data from these two tests mapped onto separate factors. Using a triple-test apparatus that allows quasi-simultaneous testing in the elevated plus maze, open field test, and lightdark box, others have estimated that the overlap in anxietyrelated measures between the elevated plus maze and the open field is as low as 15\% (Fraser et al, 2010). Thus, even though both paradigms assess conflict/avoidance behavior, they are not interchangeable.

Regarding exploratory behavior, others (Ansorge et al, 2008; Ansorge et al, 2004; Karpova et al, 2009; Popa et al, 2008) and we report remarkably similar findings wherein postnatal FLX is associated with decreased exploratory behavior and increased anxiety-related behavior in the open field (but not the elevated plus maze)-changes that are similar to those occurring in SERT-deficient mice. However, SERT-deficient mice show altered $5-\mathrm{HT}_{1 \mathrm{~A}}$-autoreceptor function and extracellular serotonin levels, whereas postnatal FLX-exposed mice do not, suggesting that it is unlikely these specific alterations in the serotonin system underlie behavioral changes in the latter. This does not preclude adaptive changes in other aspects of the serotonin system in mice with early FLX exposure, eg, serotonin receptor subtypes other than $5-\mathrm{HT}_{1 \mathrm{~A}}$ autoreceptors.

Depression-related behavior is more challenging to assess in rodent models. This behavioral domain is commonly evaluated using the forced swim test, and some have argued that in addition to predicting antidepressant efficacy, depressive-like behavior or behavioral despair can be measured by this test (Lucki, 1997). Behavior in the forced swim test was previously evaluated in postnatal antidepressant-treated rodents, as well as rats and mice with constitutive SERT deficiency (Kalueff et al, 2006; Karpova et al, 2009; Popa et al, 2008). Conclusions regarding similarities (or lack thereof) between these models are not clear-cut given inconsistencies in findings across studies. We did not observe differences in immobility on either of 2 consecutive days of forced swim testing (Supplementary Table S2), therefore we conclude that forced swim behavior is unaffected under our study conditions in both models of SERT disruption.

Reductions in 5- $\mathrm{HT}_{1 \mathrm{~A}}$ binding were previously reported in DRN $(-50 \%)$ and MRN $(-30 \%)$ in female SERT $-/-$ mice and in DRN $(-30 \%)$ in male SERT $-/-$ mice (Li et al, 2000). Decreases in 8-OH-DPAT-stimulated $\left[{ }^{35} \mathrm{~S}\right] \mathrm{GTP} \gamma \mathrm{S}$ binding of a similar magnitude were attributed to reduced $5-\mathrm{HT}_{1 \mathrm{~A}}$-autoreceptor expression in this previous study. Notably, complete loss of $5-\mathrm{HT}_{1 \mathrm{~A}}$-autoreceptor-mediated hypothermia in SERT $-I-$ mice cannot be accounted for by these modest reductions in $5-\mathrm{HT}_{1 \mathrm{~A}}$ autoreceptors. Here potentiated $5-\mathrm{HT}_{1 \mathrm{~A}}$-autoreceptor function in postnatal ESC-treated mice also was not explained by comparable increases in receptor binding or receptor-G-protein interactions. Together, these findings suggest that regulation at other levels, eg, plasma membrane localization (Descarries and Riad, 2012) or effector/signaling cascades, underlies adaptive differences in $5-\mathrm{HT}_{1 \mathrm{~A}}$-autoreceptor function in SERT $-/-$ mice and postnatal ESC-treated mice.

Increased hippocampal extracellular serotonin concomitant with desensitization and partial downregulation of $5-\mathrm{HT}_{1 \mathrm{~A}}$ autoreceptors appear to be direct responses to permanent loss of SERT, which begins during prenatal development and continues throughout life (Figure 1a). In addition to the hippocampus, we previously reported gene-dose-dependent increases in extracellular serotonin in the striatum and frontal cortex (Mathews et al, 2004), suggesting global effects of SERT deficiency on serotonin neurotransmission. In contrast, postnatal administration of SSRIs inhibits serotonin uptake during a limited developmental time frame. Development of the serotonin system prior to this period is unaffected in postnatal SSRI-treated mice. After the exposure period, a persistent change in hippocampal serotonin transmission takes place in mice exposed to ESC but not FLX. Early exposure to ESC might influence developmental trajectories associated with SERT expression or function (Daws et al, 2007). Others have reported reduced SERT immunoreactivity $(-40 \%)$ in medial prefrontal cortex and somatosensory cortex in adult rats treated postnatally with $( \pm$ ) citalopram (Maciag et al, 2006). Alternately, neonatal serotonin neuronal arborization might be reduced (Maciag et al, 2006), leading to decreased innervation of hippocampus and low extracellular serotonin 
and SERT levels in adult mice with postnatal ESC exposure. We observed reduced anxiety-related behavior as early as P50 in mice exposed to ESC during early postnatal development; therefore, serotonin system changes begin during or prior to adolescence.

Comparing raw data for saline-injected SERT $+I+$ mice $v s$ unhandled SERT $+I+$ mice suggests increased adult body weight (Supplementary Figures S2 and S3), hyperserotonemia (Figure 5) and increased anxiety-related behavior (Supplementary Table S2) in the former. Thus an alternate interpretation of the study findings is that the postnatal injection paradigm is stressful to neonates. Moreover, the effects of postnatal injection stress might be reversed by postnatal ESC and, in the case of body weight, postnatal ESC or FLX. We caution that the study strategy does not support direct statistical comparisons between the two adult control groups as the study was designed to have two separate arms: drug-treatment and constitutive genetic-deficiency arms. Mice for the drug-treated arm were generated from SERT $+I+$ parents that were offspring of SERT $+I-x$ SERT $+/$ - matings. Mice for the genetic arm were generated directly from SERT $+I-\times$ SERT $+I-$ matings. This strategy enabled us to provide mice for both study arms on the same genetic background. It also avoided injecting SERT $-I-$ mice, which are hyper-responsive to stress (Li et al, 1999; Tjurmina et al, 2002). We do not know if genotype-related differences in maternal behavior or in utero/postnatal exposure to different genotype sibling influence body weight, serotonin transmission, or anxietyrelated behavior, which could also account for differences in the saline-injected and uninjected control groups.

Nevertheless, we investigated the potential for postnatal injection stress to influence behavior and body weight in periadolescent mice. This experiment included the salineinjected and uninjected control groups in a direct comparison design. We did not observe statistically significant behavior (Figure 2) or body weight (Supplementary Figure S2) differences between control groups during adolescence. Hence, we did not include unhandled control groups in the adult drug-treatment portion of the study. In the future, it may be interesting to investigate the effects of postnatal injection stress or other types of early life stressors as a function of SERT genotype. Otherwise, we are not aware of alternate means of administering drugs to early postnatal mice, eg, they are too small for minipumps, drugs administered to lactating mothers via drinking water are unlikely to achieve appropriate drug levels in nursing pups as SSRIs do not accumulate in milk to an appreciable extent (Suri et al, 2002). We are exploring RNAi approaches and/or transient genetic knockdown strategies to avoid daily postnatal injections and potential off-target drug effects in future studies. Given the current findings, we also intend to expand upon the present behavioral comparisons using a broader array of tests.

Notably, with the exception of reduced adult body weights in male mice, the two SSRIs studied here produced dissimilar outcomes. Postnatal ESC exposure was predominantly associated with persistent reductions in anxietyrelated behavior in the elevated plus maze and hyposerotonemia, whereas lasting increases in anxiety-like behavior specific to the open field and decreases in exploratory behavior were cardinal features of postnatal FLX exposure.
Although all SSRIs share the ability to inhibit SERT with high affinity, each SSRI differs in chemical structure and therefore is capable of interacting uniquely with other biological targets, most of which are unknown. Differences in adult behavior and physiology following postnatal exposure to specific antidepressants may be due to differences in allosteric interactions with SERT or off-target effects (Carrasco and Sandner, 2005; Zhong et al, 2012). Furthermore, FLX but not citalopram requires norepinephrine to manifest antidepressant behavioral effects (Cryan et al, 2004), thus adult outcomes associated with early developmental FLX but not ESC exposure may involve changes in noradrenergic system function. Moreover, while the doses of FLX and ESC administered here have been shown to produce serum drug levels at P21 in the human therapeutic range, the half-lives of FLX and ESC differ, and it has been suggested that P5-P21 dosing with ESC may not produce the steady-state drug levels similar to postnatal FLX dosing (Ansorge et al, 2008; Popa et al, 2008). Consequently, pharmacokinetic effects could contribute to adult differences between postnatal ESC- and FLX-exposed mice.

One additional point that merits consideration is that adult body weight reductions mostly specific to male mice (Supplementary Figure S4) were similar for ESC vs FLX exposure even though behavioral changes associated with these two drugs were different and present in male and female mice. In light of the latter, we suspect that long-term behavioral consequences of early life SSRI exposure are not strongly tied to decreased body weight. However, we cannot separate potential interactions between altered growth in male mice following early exposure to SSRIs from long-term behavioral consequence.

Further work will be needed to uncover the reasons for the differences in the developmental effects of ESC $v s$ FLX and to extend the current findings to other SSRIs commonly used to treat depression and anxiety during pregnancy. Importantly, antidepressant responses to different SSRIs vary in patients. The effects of antidepressant treatment during pregnancy on human offspring are controversial (Oberlander et al, 2009). Nonetheless, outcomes associated with antidepressant therapy need to be weighed against those associated with foregoing treatment for major depressive and anxiety disorders as untreated maternal depression and anxiety have recognized effects on developmental and neurobehavioral outcomes in children (Brand and Brennan, 2009).

Human serotonin transmission likely spans a continuum of states ranging from low to high serotonergic tone (Murphy et al, 2008a; Oberlander et al, 2009). Current antidepressant therapies are ineffective in treating anxiety and depression in a large numbers of patients, and advances in predicting individual responses are hindered by difficulties associated with characterizing complex influences of genetic and environmental factors on serotonergic transmission in humans. Highly controlled animal models, such as those studied here, represent avenues by which to identify factors potentially influencing behavioral domains associated with emotion-related disorders. To translate information from animal models, we developed methods to assess clinically relevant serotonin uptake in human peripheral blood cells (Beikmann et al, 2013; Leuchter et al, 2010), which could enable personalized medicine strategies 
targeting pharmacotherapies with different mechanisms to patients suffering from depression and/or anxiety disorders based on SERT functional status. In the future, these methods could also be used to investigate the effects of early SSRI exposure and SLC6A4 gene variants on adult human serotonergic phenotypes.

\section{FUNDING AND DISCLOSURE}

Support from the National Institute of Mental Health (MH064756, MH086108), the Brain and Behavior Research Foundation (formerly NARSAD), the Shirley and Stefan Hatos Foundation, and the UCLA Weil Endowment Fund are gratefully acknowledged. The content is solely the responsibility of the authors and does not necessarily represent the official views of the National Institutes of Health. During the past 2 years, AMA has received compensation from Forest Laboratories (Actavis) as a consultant, in addition to income from primary employers. The remaining authors declare that, except for income received from primary employers, no financial support or compensation has been received from any individual or corporate entity over the past 3 years for research or professional service, and there are no personal financial holdings that could be perceived as constituting a potential conflict of interest.

\section{ACKNOWLEDGEMENTS}

The authors thank Mr Jeffrey Xu and Ms Marisela Valdez for technical assistance.

\section{REFERENCES}

Altieri S, Singh Y, Sibille E, Andrews A (2012). Serotonergic pathways in depression. In: Lopez-Munoz F, Alamo C (eds). Neurobiology of Depression. CRC Press, Taylor \& Francis Group: Boca Raton, FL, USA, pp 143-170.

Altieri SC, Garcia-Garcia AL, Leonardo ED, Andrews AM (2013). Rethinking 5-HT(1A) receptors: emerging modes of inhibitory feedback of relevance to emotion-related behavior. ACS Chem Neurosci 4: 72-83.

Ansorge MS, Morelli E, Gingrich JA (2008). Inhibition of serotonin but not norepinephrine transport during development produces delayed, persistent perturbations of emotional behaviors in mice. J Neurosci 28: 199-207.

Ansorge MS, Zhou M, Lira A, Hen R, Gingrich JA (2004). Early-life blockade of the 5-HT transporter alters emotional behavior in adult mice. Science 306: 879-881.

Beikmann BS, Tomlinson ID, Rosenthal SJ, Andrews AM (2013). Serotonin uptake is largely mediated by platelets versus lymphocytes in peripheral blood cells. ACS Chem Neurosci 4: 161-170.

Bengel D, Murphy DL, Andrews AM, Wichems CH, Feltner D, Heils A et al (1998). Altered brain serotonin homeostasis and locomotor insensitivity to 3, 4-methylenedioxymethamphetamine ('Ecstasy') in serotonin transporter-deficient mice. Mol Pharmacol 53: 649-655.

Borsini F, Lecci A, Sessarego A, Frassine R, Meli A (1989). Discovery of antidepressant activity by forced swimming test may depend on pre-exposure of rats to a stressful situation. Psychopharmacology (Berl) 97: 183-188.
Brand SR, Brennan PA (2009). Impact of antenatal and postpartum maternal mental illness: how are the children? Clin Obstet Gynecol 52: 441-455.

Brigman JL, Mathur P, Lu L, Williams RW, Holmes A (2009). Genetic relationship between anxiety-related and fear-related behaviors in BXD recombinant inbred mice. Behav Pharmacol 20: 204-209.

Burke TF, Advani T, Adachi M, Monteggia LM, Hensler JG (2013). Sensitivity of hippocampal 5-HT1A receptors to mild stress in BDNF-deficient mice. Int J Neuropsychopharmacol 16: 631-645.

Cahir M, Ardis T, Reynolds GP, Cooper SJ (2007). Acute and chronic tryptophan depletion differentially regulate central 5-HT1A and 5-HT2A receptor binding in the rat. Psychopharmacology (Berl) 190: 497-506.

Carrasco JL, Sandner C (2005). Clinical effects of pharmacological variations in selective serotonin reuptake inhibitors: an overview. Int J Clin Pract 59: 1428-1434.

Carroll JC, Boyce-Rustay JM, Millstein R, Yang R, Wiedholz LM, Murphy DL et al (2007). Effects of mild early life stress on abnormal emotion-related behaviors in 5-HTT knockout mice. Behav Genet 37: 214-222.

Casper RC, Fleisher BE, Lee-Ancajas JC, Gilles A, Gaylor E, DeBattista A et al (2003). Follow-up of children of depressed mothers exposed or not exposed to antidepressant drugs during pregnancy. J Pediatr 142: 402-408.

Caspi A, Hariri AR, Holmes A, Uher R, Moffitt TE (2010). Genetic sensitivity to the environment: The case of the serotonin transporter gene and its implications for studying complex diseases and traits. Am J Psychiatry 167: 509-527.

Clancy B, Kersh B, Hyde J, Darlington RB, Anand KJ, Finlay BL (2007). Web-based method for translating neurodevelopment from laboratory species to humans. Neuroinformatics 5: 79-94.

Cryan JF, O'Leary OF, Jin SH, Friedland JC, Ouyang M, Hirsch BR et al (2004). Norepinephrine-deficient mice lack responses to antidepressant drugs, including selective serotonin reuptake inhibitors. Proc Natl Acad Sci USA 101: 8186-8191.

Daws LC, Munn JL, Valdez MF, Frosto-Burke T, Hensler JG (2007). Serotonin transporter function, but not expression, is dependent on brain-derived neurotrophic factor (BDNF): In vivo studies in BDNF-deficient mice. J Neurochem 101: 641-651.

Descarries L, Riad M (2012). Effects of the antidepressant fluoxetine on the subcellular localization of 5-HT1A receptors and SERT. Philos Trans R Soc Lond B Biol Sci 367: 2416-2425.

Fraser LM, Brown RE, Hussin A, Fontana M, Whittaker A, O'Leary TP et al (2010). Measuring anxiety- and locomotionrelated behaviours in mice: a new way of using old tests. Psychopharmacology 211: 99-112.

Gross C, Santarelli L, Brunner D, Zhuang X, Hen R (2000). Altered fear circuits in 5-HT(1A) receptor KO mice. Biol Psychiatry 48: 1157-1163.

Guilloux JP, Seney M, Edgar N, Sibille E (2011). Integrated behavioral z-scoring increases the sensitivity and reliability of behavioral phenotyping in mice: relevance to emotionality and sex. J Neurosci Methods 197: 21-31.

Hensler JG (2002). Differential regulation of 5-HT1A receptor-G protein interactions in brain following chronic antidepressant administration. Neuropsychopharmacology 26: 565-573.

Hjorth S, Auerbach SB (1994). Further evidence for the importance of 5-HT1A autoreceptors in the action of selective serotonin reuptake inhibitors. Eur J Pharmacol 260: 251-255.

Hjorth S, Westlin D, Bengtsson HJ (1997). WAY100635-induced augmentation of the 5-HT-elevating action of citalopram: Relative importance of the dose of the 5-HT1A (auto)receptor blocker versus that of the 5-HT reuptake inhibitor. Neuropharmacology 36: 461-465.

Holmes A, Li Q, Murphy DL, Gold E, Crawley JN (2003a). Abnormal anxiety-related behavior in serotonin transporter null mutant mice: The influence of genetic background. Genes Brain Behav 2: 365-380. 
Holmes A, Rodgers RJ (1998). Responses of Swiss-Webster mice to repeated plus-maze experience: Further evidence for a qualitative shift in emotional state? Pharmacol Biochem Behav 60: $473-488$.

Holmes A, Yang RJ, Lesch K-P, Crawley JN, Murphy DL (2003b). Mice lacking the serotonin transporter exhibit 5-HT(1A) receptor-mediated abnormalities in tests for anxiety-like behavior. Neuropsychopharmacology 28: 2077-2088.

Homberg JR, Olivier JD, Smits BM, Mul JD, Mudde J, Verheul M et al (2007). Characterization of the serotonin transporter knockout rat: a selective change in the functioning of the serotonergic system. Neuroscience 146: 1662-1676.

Homberg JR, Schubert D, Gaspar P (2010). New perspectives on the neurodevelopmental effects of SSRIs. Trends Pharmacol Sci 31: 60-65.

Hu XZ, Lipsky RH, Zhu G, Akhtar LA, Taubman J, Greenberg BD et al (2006). Serotonin transporter promoter gain-of-function genotypes are linked to obsessive-compulsive disorder. Am J Hum Genet 78: 815-826.

Jennings KA, Loder MK, Sheward WJ, Pei Q, Deacon RM, Benson MA et al (2006). Increased expression of the 5-HT transporter confers a low-anxiety phenotype linked to decreased 5-HT transmission. J Neurosci 26: 8955-8964.

Joeyen-Waldorf J, Edgar N, Sibille E (2009). The roles of sex and serotonin transporter levels in age- and stress-related emotionality in mice. Brain Res 1286: 84-93.

Kalueff AV, Gallagher PS, Murphy DL (2006). Are serotonin transporter knockout mice 'depressed'? Hypoactivity but no anhedonia. Neuroreport 17: 1347-1351.

Kalueff AV, Jensen CL, Murphy DL (2007). Locomotory patterns, spatiotemporal organization of exploration and spatial memory in serotonin transporter knockout mice. Brain Res 1169: 87-97.

Karpova NN, Lindholm J, Pruunsild P, Timmusk T, Castren E (2009). Long-lasting behavioural and molecular alterations induced by early postnatal fluoxetine exposure are restored by chronic fluoxetine treatment in adult mice. Eur Neuropsychopharmacol 19: 97-108.

Lapiz-Bluhm MD, Bondi CO, Doyen J, Rodriguez GA, Bedard-Arana T, Morilak DA (2008). Behavioural assays to model cognitive and affective dimensions of depression and anxiety in rats. J Neuroendocrinol 20: 1115-1137.

Leuchter AF, Cook IA, Hamilton SP, Narr KL, Toga A, Hunter AM et al (2010). Biomarkers to predict antidepressant response. Curr Psychiatry Rep 12: 553-562.

Li Q, Wichems C, Heils A, Lesch KP, Murphy DL (2000). Reduction in the density and expression, but not G-protein coupling, of serotonin receptors (5-HT1A) in 5-HT transporter knock-out mice: gender and brain region differences. J Neurosci 20: $7888-7895$.

Li Q, Wichems C, Heils A, Van De Kar LD, Lesch KP, Murphy DL (1999). Reduction of 5-hydroxytryptamine (5-HT)(1A)-mediated temperature and neuroendocrine responses and 5-HT(1A) binding sites in 5-HT transporter knockout mice. J Pharmacol Exp Ther 291: 999-1007.

Licht CL, Kirkegaard L, Zueger M, Chourbaji S, Gass P, Aznar S et al (2010). Changes in 5-HT4 receptor and 5-HT transporter binding in olfactory bulbectomized and glucocorticoid receptor heterozygous mice. Neurochem Int 56: 603-610.

Lindsley CW (2012). The top prescription drugs of 2011 in the United States: antipsychotics and antidepressants once again lead CNS therapeutics. ACS Chem Neurosci 3: 630-631.

Lucki I (1997). The forced swimming test as a model for core and component behavioral effects of antidepressant drugs. Behav Pharmacol 8: 523-532.

Luellen BA, Bianco LE, Schneider LM, Andrews AM (2007). Reduced brain-derived neurotrophic factor is associated with a loss of serotonergic innervation in the hippocampus of aging mice. Genes Brain Behav 6: 482-490.
Maciag D, Simpson KL, Coppinger D, Lu Y, Wang Y, Lin RCS et al (2006). Neonatal antidepressant exposure has lasting effects on behavior and serotonin circuitry. Neuropsychopharmacology 31: 47-57.

Martin KF, Phillips I, Hearson M, Prow MR, Heal DJ (1992). Characterization of 8-OH-DPAT-induced hypothermia in mice as a 5-HT1A autoreceptor response and its evaluation as a model to selectively identify antidepressants. Br J Pharmacol 107: 15-21.

Mathews TA, Fedele DE, Coppelli FM, Avila AM, Murphy DL, Andrews AM (2004). Gene dose-dependent alterations in extraneuronal serotonin but not dopamine in mice with reduced serotonin transporter expression. J Neurosci Methods 140: 169-181.

McQuade R, Sharp T (1997). Functional mapping of dorsal and median raphe 5-hydroxytryptamine pathways in forebrain of the rat using microdialysis. J Neurochem 69: 791-796.

Mirmiran M, van de Poll NE, Corner MA, van Oyen HG, Bour HL (1981). Suppression of active sleep by chronic treatment with chlorimipramine during early postnatal development: effects upon adult sleep and behavior in the rat. Brain Res 204: 129-146.

Misri S, Reebye P, Kendrick K, Carter D, Ryan D, Grunau RE et al (2006). Internalizing behaviors in 4-year-old children exposed in utero to psychotropic medications. Am J Psychiatry 163: 1026-1032.

Mitchell C, Notterman D, Brooks-Gunn J, Hobcraft J, Garfinkel I, Jaeger K et al (2011). Role of mother's genes and environment in postpartum depression. Proc Natl Acad Sci USA 108: 8189-8193.

Murphy DL, Fox MA, Timpano KR, Moya PR, Ren-Patterson R, Andrews AM et al (2008a). How the serotonin story is being rewritten by new gene-based discoveries principally related to SLC6A4, the serotonin transporter gene, which functions to influence all cellular serotonin systems. Neuropharmacology 55: 932-960.

Murphy DL, Lesch K-P (2008b). Targeting the murine serotonin transporter: insights into human neurobiology. Nat Rev Neurosci 9: 85-96.

Murphy DL, Maile MS, Vogt NM (2013). 5HTTLPR: white knight or dark blight? ACS Chem Neurosci 4: 13-15.

Murphy DL, Moya PR (2011). Human serotonin transporter gene (SLC6A4) variants: their contributions to understanding pharmacogenomic and other functional $\mathrm{GxG}$ and $\mathrm{GxE}$ differences in health and disease. Curr Opin Pharmacol 11: 3-10.

Nordeng H, Lindemann R, Perminov KV, Reikvam A (2001). Neonatal withdrawal syndrome after in utero exposure to selective serotonin reuptake inhibitors. Acta Paediatr 90: 288-291.

Oberlander TF, Gingrich JA, Ansorge MS (2009). Sustained neurobehavioral effects of exposure to SSRI antidepressants during development: molecular to clinical evidence. Clin Pharmacol Ther 86: 672-677.

Oberlander TF, Warburton W, Misri S, Aghajanian J, Hertzman C (2006). Neonatal outcomes after prenatal exposure to selective serotonin reuptake inhibitor antidepressants and maternal depression using population-based linked health data. Arch Gen Psychiatry 63: 898-906.

Olivier JD, Van Der Hart MG, Van Swelm RP, Dederen PJ, Homberg JR, Cremers T et al (2008). A study in male and female 5-HT transporter knockout rats: an animal model for anxiety and depression disorders. Neuroscience 152: 573-584.

Paxinos G, Franklin KBJ (2001). The Mouse Brain in Stereotaxic Coordinates. 2nd edn. Academic Press: New York, NY, USA.

Perez XA, Andrews AM (2005). Chronoamperometry to determine differential reductions in uptake in brain synaptosomes from serotonin transporter knockout mice. Anal Chem 77: 818-826.

Popa D, Cerdan J, Repérant C, Guiard BP, Guilloux J-P, David DJ et al (2010). A longitudinal study of 5-HT outflow during chronic fluoxetine treatment using a new technique of chronic microdialysis in a highly emotional mouse strain. Eur $J$ Pharmacol 628: 83-90. 
Popa D, Lena C, Alexandre C, Adrien J (2008). Lasting syndrome of depression produced by reduction in serotonin uptake during postnatal development: evidence from sleep, stress, and behavior. J Neurosci 28: 3546-3554.

Porsolt RD, Brossard G, Hautbois C, Roux S (2001). Rodent models of depression: forced swimming and tail suspension behavioral despair tests in rats and mice. Curr Protoc Neurosci Chapter 8: Unit 8.10A.

Porsolt RD, Le Pichon M, Jalfre M (1977). Depression: a new animal model sensitive to antidepressant treatments. Nature 266: 730-732.

Richardson-Jones JW, Craige CP, Guiard BP, Stephen A, Metzger KL, Kung HF et al (2010). 5-HT1A autoreceptor levels determine vulnerability to stress and response to antidepressants. Neuron 65: 40-52.

Richardson-Jones JW, Craige CP, Nguyen TH, Kung HF, Gardier AM, Dranovsky A et al (2011). Serotonin-1A autoreceptors are necessary and sufficient for the normal formation of circuits underlying innate anxiety. J Neurosci 31: 6008-6018.

Richer M, Hen R, Blier P (2002). Modification of serotonin neuron properties in mice lacking 5-HT1A receptors. Eur J Pharmacol 435: 195-203.

Rossi DV, Burke TF, Hensler JG (2008a). Differential regulation of serotonin-1A receptor-stimulated [35S]GTP gamma S binding in the dorsal raphe nucleus by citalopram and escitalopram Eur J Pharmacol 583: 103-107.

Rossi DV, Burke TF, McCasland M, Hensler JG (2008b). Serotonin$1 \mathrm{~A}$ receptor function in the dorsal raphe nucleus following chronic administration of the selective serotonin reuptake inhibitor sertraline. J Neurochem 105: 1091-1099.

Shen Q, Lal R, Luellen BA, Earnheart JC, Andrews AM, Luscher B (2010). Gamma-Aminobutyric acid-type A receptor deficits cause hypothalamic-pituitary-adrenal axis hyperactivity and antidepressant drug sensitivity reminiscent of melancholic forms of depression. Biol Psychiatry 68: 512-520.

Sibille E, Lewis DA (2006). SERT-ainly involved in depression, but when? Am J Psychiatry 163: 8-11.

Sinton CM, Fallon SL (1988). Electrophysiological evidence for a functional differentiation between subtypes of the 5-HT1 receptor. Eur J Pharmacol 157: 173-181.
Suri R, Stowe ZN, Hendrick V, Hostetter A, Widawski M, Altshuler LL (2002). Estimates of nursing infant daily dose of fluoxetine through breast milk. Biol Psychiatry 52: 446-451.

Szapacs M, Mathews T, Tessarollo L, Lyons WE, Andrews A (2004). Exploring the relationship between serotonin and brain-derived neurotrophic factor: analysis of BDNF protein and extraneuronal 5-HT in mice with reduced serotonin transporter or BDNF expression. J Neurosci Methods 140: 81-92.

Tao R, Ma Z, Auerbach SB (2000). Differential effect of local infusion of serotonin reuptake inhibitors in the raphe versus forebrain and the role of depolarization-induced release in increased extracellular serotonin. J Pharmacol Exp Ther 294: 571-579.

Tjurmina OA, Armando I, Saavedra JM, Goldstein DS, Murphy DL (2002). Exaggerated adrenomedullary response to immobilization in mice with targeted disruption of the serotonin transporter gene. Endocrinology 143: 4520-4526.

Vogel G, Neill D, Hagler M, Kors D (1990). A new animal model of endogenous depression: a summary of present findings. Neurosci Biobehav Rev 14: 85-91.

Walf AA, Frye CA (2007). The use of the elevated plus maze as an assay of anxiety-related behavior in rodents. Nat Protoc 2: 322-328.

Wenthur CJ, Bennett MR, Lindsley CW (2014). Classics in chemical neuroscience: fluoxetine (Prozac). ACS Chem Neurosci 5: 14-23.

Workman AD, Charvet CJ, Clancy B, Darlington RB, Finlay BL (2013). Modeling transformations of neurodevelopmental sequences across mammalian species. J Neurosci 33: 7368-7383.

Yang H, Thompson AB, McIntosh BJ, Altieri SC, Andrews AM (2013). Physiologically relevant changes in serotonin resolved by fast microdialysis. ACS Chem Neurosci 4: 790-798.

Yu Q, Teixeira CM, Mahadevia D, Huang Y, Balsam D, Mann JJ et al (2014). Dopamine and serotonin signaling during two sensitive developmental periods differentially impact adult aggressive and affective behaviors in mice. Mol Psychiatry. 19: 688-698.

Zhong H, Haddjeri N, Sanchez C (2012). Escitalopram, an antidepressant with an allosteric effect at the serotonin transporter-a review of current understanding of its mechanism of action. Psychopharmacology 219: 1-13.

Supplementary Information accompanies the paper on the Neuropsychopharmacology website (http://www.nature.com/npp) 